\section{Evolution of Marine Mammal Hunting: A View from the California and Oregon Coasts}

\section{William R. HildebrandT}

Far Western Anthropological Research Group, P.O. Box 413, Davis, California 95617

AND

TERRY L. JONES

Department ${ }_{f}$ Anthropology, University of California, Davis, California 95616

Received July 22, 1991

Marine mammals constitute . . . an integral part of the marine ecosystem usually as top predators. Hunting of cetaceans and pinnipeds for skins, meat and blubber has of course gone on from the earliest recorded times. At various periods ... the hunting of them intensified to the point at which it caused serious depletion. Although accurate records are not available, there is little doubt that many marine mammal populations were reduced to a small fraction (perhaps no more than tenth or so) of their former levels. Some like the sea otter, disappeared from parts of their range ...

(Beverton 1985:3-4)

With the increased recognition of hunter-gatherer cultural complexity that emerged in the 1980s (Price and Brown 1985), maritime adaptations continue to demonstrate their need for special attention within the realm of hunter-gatherer research. In the seminal work on this subject, Yesner (1980) delineated attributes of marine environments that offer unusual opportunities for foraging populations. Since then, a statistical correlation between sedentism and coastal environments has been reported (Pálsson 1988), and a number of examples of intensification within coastal contexts have been described (Ames 1985; C. King 1990). The coastal resource receiving most attention to date has been shellfish, no doubt because shell middens are abundant worldwide. Shellfish, however, are a relatively simple resource; they occur in a variety of habitats, are relatively uniform in their accessibility to human forgers, and are easy to procure, even by nonhuman primates (Carpenter 1887). Marine mammals, on the other hand, particularly seals and sea lions, are among the most complex resources pursued by human hunters. During the course of their life cycle these animals strike drastically different poses as prospective quarry; when occupying terrestrial breeding sites, they are abundant, visible, and immobile; when at sea, they are significantly more elusive, and difficult to dispatch and retrieve when encountered.

The economic implications of seal and sea lion exploitation have been addressed by Clark (1946), Osborne (1977), Hildebrandt (1981, 1984a), Marean (1986), and Lyman (1989), but many issues still remain unresolved. One problem involves a proposal by Hildebrandt $(1981,1984 a)$ regarding the late prehistoric hunting of pinnipeds along the northern coast of California. Hildebrandt has proposed that the archaeological occurrence of pinniped species historically known to avoid nearshore habitats (Steller sea lion [Eumetopias jubata], California sea lion [Zalophus californianus], and northern fur seal [Callorhinus ursinus]) indicated the use of watercraft to pursue these animals at distant offshore rocks and islands. Supported by ethnographic accounts, this use of oceangoing canoes was further envisioned as an important component of an intensified Late Period hunting adaptation that included sophisticated sociopolitical organization. Lyman (1989) supplemented Hildebrandt's ethnographic and faunal data with additional studies of archaeofaunas from the Oregon coast, and historic accounts of the slaughter of seals and sea lions by EuroAmericans, and posed an alternative to Hildebrandt's proposal: the present day restriction of sea lions and fur seals to offshore sites is a product of overexploitation of these animals during historic times, and prior to historic contact, these animals could have been hunted on the mainland. He further concluded that it is unnecessary and, in fact, unjustified to invoke the use of sophisticated watercraft to explain the presence of these remains in mainland sites. We find ourselves in partial agreement with the inferences that Lyman has drawn from the historic record, as do members of the biological community (e.g., Beverton 1985). In this paper, we expand the temporal and geographic scale of those studies to present yet another interpretation of the relationship between the coastal hunter-gatherers of western North America and pinniped populations of the northeastern Pacific. Simply stated, we argue that the depletion of seal and sea lion populations and their restriction to offshore rookeries and haulouts is an anthropogenic phenomenon not restricted to the historic era. Rather, the process of extirpation described by Beverton (1985) is one that began with the initial prehistoric settlement of coastal environments. We derive these conclusions from seal and sea lion population ecology, optimization theory, and dated faunal assemblages from the California and Oregon coastlines. In combination, these data suggest a process of human overexploitation which has affected the character of hunter-gatherer intensification within this region. 


\section{POPULATION ECOLOGY OF SEALS AND SEA LIONS}

The literature on pinniped ecology is profuse, diverse and incongruent. Interest in this topic has risen greatly in the last two decades partially as a by-product of the growth in pinniped populations in those areas where human predation has recently been curtailed. In many such localities, seal and sea lion numbers are now so high that the animals have become a major issue of marine resource conservation and management (Beddington et al. 1985; Geraci and St. Aubin 1990). The biological community is largely in agreement, however, that pinnipeds are K-strategists (Eberhardt 1977); they have a low rate of population increase, delayed reproduction, small litter size, large body mass, high survival, long life span, and relatively stable populations (Delany 1982:33). It has further been found that low reproductive rates could only have evolved in a stable environment because populations with a low reproductive potential are unable to withstand increased mortality without decline (Mertz 1971). Populations of marine mammals are particularly sensitive to depletion through exploitation and inclined to recover from such depletion very slowly (Estes 1979:1010).

Three competing factors have been proposed as the controlling agents of pinniped population size: food resources, breeding space, and predation (McLaren and Smith 1985:66). Of these, food availability and breeding space are believed to be the most important. Estes (1979:1015) has argued that before human (e.g., historic) exploitation, many species of marine mammals were limited only by the availability of food. Others cite limitations in breeding space as a major limit to population growth, as pup survival rates decrease as overcrowding increases (Coulson and Hickling 1964; Reiter et al. 1981). The size of pinniped populations is also affected by both terrestrial (bears, eagles, and jackals) and marine (killer whales, walruses, and sharks) predators (Riedman 1990:117-119). Although pelagic predation is generally assumed to represent the greatest nonhuman impact to pinniped populations (Boulva and McLaren 1979:22), the restriction of most modern pinniped breeding sites to islands lacking terrestrial predators suggests that some types of terrestrial predation have had an effect on pinniped populations (Stirling 1983:511). Le Bouef (1981: 294) believes the predatory threat of bears, wolves, coyotes, and mountain lions was severe enough to keep breeding sites off of the mainland. With the present-day absence of both human and nonhuman predation, many species continue to show a propensity toward offshore islands and/ or inaccessible nearshore locations for breeding sites; however, some, notably the northern elephant seal (Mirounga angustirostris), have expanded their breeding sites to mainland locations. This colonization has come only after a long, slow population revival, following near extermi- nation at the hands of commercial sealers in the 19th century. Both the Guadalupe fur seal (Arctocephalus townsendi) and the elephant seal were considered extinct by 1869 (Le Bouef 1981:293), and their disappearance contributed significantly to the rapid demise of the seal industry. Citing Starks (1922), Bonnot (1928, 1951) and Rowley (1929), Lyman (1989:91) suggested that much of this commercial sealing was conducted at mainland rookeries: "historic decimation of the Guadalupe fur seal on the southern California coast could be attributed to clubbing on land, and implied a similar exploitation strategy and fate for northern fur seals." In point of fact, however, Starks' account refers to activities occurring only on islands (Farallons and Guadalupe), as does Bonnot's (Prifilofs) and Rowley's (Santa Cruz, Santa Barbara, and Coronado). Lyman also (1989: 91) cites J. King (1983) and states, "bachelor pods are commercially harvested today on land with clubs." Again, this activity actually occurred on the Prifilof Islands. It is not surprising that evidence for the exploitation of mainland breeding grounds was difficult to find, as Bonnot's (1928) seminal work on the distribution of fur seal and sea lion rookeries along the coast of California indicated the near absence of mainland breeding grounds at this time. His research identified the existence of 20 rookery areas, 18 offshore rock/islands, two inaccessible onshore locations, and none on mainland beaches. Only more recently, after over 100 years free of human and nonhuman predation, have any of these $\mathrm{K}$-strategists expanded their breeding sites to easily accessible mainland locations: elephant seals were first noted on Año Nuevo Island in 1961 (Radford et al. 1965; Le Bouef 1981:297); isolated animals appeared on the mainland in the early 1970s and the first birth was recorded there in 1975 (Le Bouef 1981:299). Prior to this recent population revival, thousands of years of primarily mainland-based prehistoric human predation eliminated mainland breeding colonies, and restricted them to islands, offshore rocks, and remote mainland locations. Aquatically based historic sealers then ravaged those locations that had previously provided partial refuge from aboriginal hunters.

\section{OPTIMIZATION THEORY AND THE ABORIGINAL RESOURCE POTENTIAL OF SEALS AND SEA LIONS}

Despite occasional criticism (Jennings 1986:119; Keene 1983; Martin 1983) optimal foraging theory continues to demonstrate its utility in providing insight into hunter-gatherer subsistence practices, particularly in coastal zones (Glassow and Wilcoxon 1988). In optimization terms, seal and sea lion rookeries represent one of the highest ranked foods available to human foraging populations in western North America. While this utility cannot be quantified calorically at present, an intuitive assessment 
of the size and relative mobility of these animals seems more than adequate to justify such a conclusion. Following the basic tenets of optimal foraging, these animals could have been exploited with existing technology early in the process of New World colonization, with the exact timing of initial exploitation varying relative to the utility of adjacent terrestrial habitats. Prior to the arrival of humans in the New World, seal and sea lion populations, limited primarily by food availability (assuming minimal nonhuman terrestrial predation), must have been larger and therefore probably included at least some mainland rookeries. Because of their economic utility and vulnerability to humans, these animals would have been hunted frequently and effectively enough to drive them from their mainland breeding grounds.

Optimal foraging theory further suggests that a prey species probably should not be exploited to its complete annihilation, since before that point would be reached, prey density would decrease to such a degree that the costs associated with continued pursuit would become inordinately high (Smith 1983:632). This logic predicts the initial elimination of seal and sea lion rookeries from the mainland, followed by the more costly and therefore less extensive exploitation of offshore breeding sites; transportation costs and the greater uncertainty of success would have limited the number of animals procured. Seals and sea lions have also demonstrated the ability to alter the geographic configuration of their breeding structure in response to fluctuations in the intensity of human predation. In South Africa seals have been found, upon the cessation of commercial exploitation, to establish new breeding sites at locations not used prior to historic slaughter (Best and Shaughnessy 1979). Such a propensity would ensure species survival despite extensive overexploitation by humans.

\section{Technological Coevolution}

Pursuit of northeastern Pacific marine mammals, optimal or otherwise, could only have been accomplished within the constraints of existing technology, but there can be little doubt that early human settlers arrived in western North America with equipment that was more than adequate to exploit terrestrial breeding sites. Accounts of historic seal hunting practices (Landberg 1965:61; Allen 1880) demonstrate that effective exploitation could be accomplished with nothing more than a club and lance. Simple, expedient watercraft like small dugouts, rafts, logs, or skin boats (Griffin 1964:225; Engelbrecht and Seyfert 1991:3) could have provided occasional, limited access to island rookeries.

Resource overexploitation and localized extirpation of mainland rookeries would, through time, provide ample incentive for technological in- novation in maritime weaponry and watercraft. Indeed, a decreased mainland presence of marine mammals and subsequent pursuit in offshore contexts appear to correlate with the initial development of sophisticated marine resource acquisition technologies. The archaeological record of western North America shows that such developments occurred relatively late in time. In northwest California, large sea mammal harpoon tips make their initial appearance ca. 900 A.D. (Hildebrandt 1981:191192), coincident with development of large ocean-going canoes. Between that date and contact, a wide variety of tip and barb forms were developed and put into use (Bennyhoff 1950:309-312; Hildebrandt 1981:103). In the Santa Barbara Channel, stone drills associated with plank canoe manufacture and bone harpoon barbs occur ca. 300-700 A.D. (C. King 1990:28, 233). More direct evidence of canoes, in the form of asphaltum plugs, has been recovered from contexts dating ca. 700-900 A.D. (C. King 1990:28, 233). As in the north, modifications and improvements were made frequently during the Late Prehistoric Period, and by the time of contact, the Chumash employed a harpoon and harpoon arrow, both with composite bone and stone points, as well as trident and simple fish spears (Hudson and Blackburn 1982:193-202). The increased sea worthiness and cargo capacity of plank canoes would significantly increase the potential for island rookery exploitation.

The substantial labor costs encumbered by the new technologies were consistent with the time-consuming and difficult pursuit strategies with which they were associated. Kroeber and Barrett described the most common techniques employed on the northwest coast of California:

. . sea lions were ordinarily got by going out on sea stacks, where the animals could be surprised and attacked, either clubbed or harpooned, according to opportunity, with boat standing to pick up the line and wear animal down. Occasionally, a hunter might cast a harpoon from a sea stack into a sea lion swimming close by (Kroeber and Barrett 1960:121).

While not the preferred method, late prehistoric and ethnographic marine mammal exploitation also included occasional pelagic pursuit. This activity was mostly undertaken in those areas where the presence of offshore rocks and islands provided incentive for the development of advanced watercraft. It was a supplement to exploitation of the primary targets:

Sea lions (and seals) were sometimes harpooned in the water but more frequently on one or another of the rocks where they came to sun themselves. (Kroeber and Barrett 1960:177)

An account written by Fray Antonio de la Ascension, a member of the 1602 Sebastian Vizcaino expedition, describes pelagic pursuit of seals among the Chumash of the Santa Barbara Channel: 
At the end of the pole they fasten a harpoon made of fishbone, and to this they tie firmly a long strong line like twine. Carrying these in their canoes, when they see in the bottom near the canoes some large fish or one of reasonable size, they strike them with these harpoons. When this is fast to the fish, they give it the line if it is a large one, and follow it, little by little nearing the beach, where they finish by killing it and drawing it on land. The small ones they at once raise into the canoe. With this artifice the Indians capture very large fish and many seals. (Wagner 1929:236)

A mission account from Baja California dating ca. 1772-1790 likewise describes sea otter hunting as generally watercraft dependent and time consuming:

He has provided a club and a long cord with two hooks, and when he discovers an otter he draws near it. The otter ordinarily swims carrying its young ones, teaching them to paddle with their little paws. Seeing the canoe she dives under the water and leaves her young on the surface. The Indian comes up immediately and ties the cord to a legtof the little otter so that one hook lies close to the foot and the other a span away. This done the Indian retires with his canoe, paying out the cord, and when a little way off jerks the cord so as to hurt the otter, and it cries out because of the pain. At its call the mother comes and sees the Indian is far away, she approaches it, clasps it and tries to take it away, but since the Indian holds tightly to the cord she cannot. Then the big otter tries by kicking its feet to get the cord off its baby and usually gets entangled with one of thee hooks. Now that it is caught the Indian comes up in his canoe with a club in his hand, gives it a blow on the head, and it is his. I have seen how much this operation requires of the poor Indians; sometimes in a whole day they get none, sometimes only one, and sometimes they lose all to a sudden surge of sea and are drowned. They also hunt them when they are asleep on the water or when they come upon the beach to rest. (Rudkin 1956:19-20).

Such risky, low-yield pursuit strategies represent the culmination of a long, diachronic progression toward decreased resource availability as a consequence of overexploitation and intensified technological response.

\section{Behavioral Variability and Species Ranking}

Behavioral and physiological variability among marine mammal species found along the coasts of northern California and Oregon has important implications for their potential utility as human resources. The Steller sea lion (Eumetopias jubata), California sea lion (Zalophus californianus), and northern fur seal (Callorhinus ursinus) are all members of the family Otaridae. This group, hereafter referred to as migratory breeders, can neither breed nor give birth while in the water. As a solution to this problem, large dominant males establish territories on offshore rocks and islands during the late spring. These areas are later occupied by harems of the much smaller females, who give birth and breed almost immediately upon arrival. Although gestation lasts for 9 months, the convergence of parturition and breeding is made possible by the delayed implantation of the fertilized egg (Maxwell 1967; Orr and Poulter 1967). After about a month, when the pups are physically able to swim, the animals disperse on their annual migration (Fiscus 1978; Mate 1975; Scheffer 1958).

Two other economically important taxa also occupy these waters, the harbor seal (Phoca vitulina) and sea otter (Enhydra lutris). Hereafter referred to as resident breeders, these species can breed and give birth in the water, are not migratory, do not form large harems, and exhibit little sexual dimorphism. Harbor seals are known to use offshore rocks and spits during the pupping season, but because the pups are born with juvenile pelage and can swim easily as newborns, such habitats are abandoned at the slightest sign of danger (Newby 1973, 1978; Ronald et al 1982; Scheffer 1958). Although sea otter pups cannot swim for about 2 weeks, they are carried on their mother's chest at all times except during periods of feeding. Buoyed by air pockets within their thick fur, pups are left floating on the surface while mothers dive for food (Kenyon 1978, 1982; Love 1990).

With the exception of the sea otter, both migratory and resident species also haulout at other times of the year. Unlike migratory species during the breeding season, all groups immediately remove themselves to the water when disturbed, quickly becoming pelagic prey. Given the technological constraints associated with pelagic hunting, migratory breeders in reproductive mode encumber substantially lower pursuit costs than do the others.

\section{THE ARCHAEOLOGY OF PINNIPED EXPLOITATION ON THE CALIFORNIA AND OREGON COASTS: ANOTHER LOOK}

The archaeology of maritime California and Oregon suggests that seal and sea lion resources were exploited by the initial coastal settlers in all locations, but that the timing of that exploitation varies with latitude as a function of the comparative value of terrestrial versus marine habitats in each latitudinal zone. Evidence for initial marine occupation is extremely early (ca. 8,000-7,000 B.C.) on the south coast, and becomes progressively more recent as one moves north, with the important exception of estuary-associated sites, which are uniformly early on the south and central coasts, and largely unsampled in the north (T. Jones 1991). Variation in the timing and intensity of marine mammal procurement is correlated with local histories of coastal settlement, therefore, our review of the archaeology of pinniped exploitation considers three discrete regions: northern California and Oregon, central California, and southern California. All three generally manifest similar diachronic patterns; migratory breeders are common in early archaeofaunal assemblages, but eventually 
decrease, being replaced by the smaller, more elusive resident breeders. The singularity of this pattern along such an extensive stretch of coast suggests that environmental forces were not affecting this transition, inasmuch as the effects of large-scale Holocene climatic oscillations were not equally uniform across this expanse.

\section{Northern California and Oregon}

The earliest evidence for human occupation in northwestern California comes from a series of Borax Lake pattern sites located $20-60 \mathrm{~km}$ inland (Fredrickson 1984; Hildebrandt and Hayes 1983). Dating approximately 4500-1500 B.C., the record consists of several small residential bases found predominately in upland settings (1400-1750 m above mean sea level), but also in lesser numbers along low elevation river terraces. Artifact assembleges reflect the activities of complete social groups and remain essentially unchanged from one environmental zone to the next. Lacking tools associated with the use of the acorn (Basgall 1987), these sites seem to represent a forager solution to subsistence-settlement organization (cf., Binford 1980).

After ca. 1000 B.C., upland areas formally occupied by a relatively open associations of pines, oaks, and a variety of shrubs were replaced by a downward migration of montane forest, significantly reducing resource productivity (West 1989, 1990). A corresponding shift is seen in the archaeological record, with upland residential bases being replaced by taskspecific assemblages largely associated with hunting. Simultaneous with this shift, lowland residential bases become more permanent, supported by increased use of salmon and acorns. Intensified use of these resources was accomplished through the development of sophisticated extractive technology (e.g., weirs) and storage (see Shalk 1977; Testart 1982). Dependence on stored resources led to the development of sedentary villages in the lowlands and task-specific sites elsewhere.

Excepting sporadic components dating ca. 500 B.C.-1 A.D. (Gould 1972; Levulett 1985), regular occupation of the northern coast does not, at present, appear to have occurred until approximately 500 A.D. As evidenced by the sites originally studied by Hildebrandt $(1981,1984 a)$, by 1000 A.D., sedentary villages were widespread, many supported by intensive use of marine resources.

Lyman's (1991) recent synthesis of Oregon coast prehistory shows patterns not unlike those manifested in northwest California. Three adaptational stages are proposed: prelittoral (before 3000 B.C.), early littoral (3000 B.C.-1 A.D.) and late littoral (after 1 A.D.). Prior to 3000 B.C. human occupation appears to have been focused on interior riverine set- tings, with marginal use of the coast. Lyman and Ross (1988) speculate that these people were generalized foragers exploiting a wide range of terrestrial resources with little emphasis on marine foods. After 3000 B.C. subsistence strategies shifted to include a coastal focus, with particular emphasis on intertidal resources. Although uncertain, a seasonally structured foraging strategy was probably in effect, with pinnipeds being of comparable importance to terrestrial game in the overall diet. The transition from early to late littoral occurred ca. 1000 B.C.-1 A.D., and is thought to have been characterized by a shift to a more logistically organized adaptive strategy. Sedentary or near sedentary villages were established on the coast coterminous with intensified fishing (both marine and anadromous) and marine mammal procurement.

The original treatment of pinniped exploitation by Hildebrandt (1981, 1984a, 1984b) and Jobson and Hildebrandt (1980) focused on seven late (after 1000 A.D.) prehistoric localities along the northernmost coast of California (Fig. 1). Due to differences in the geomorphology along the coastline, the northern group of sites (Point St. George, Stone Lagoon, and Patrick's Point) were situated adjacent to well-developed headlands with several large-scale rookeries, most ranging from 5-11 km from shore. In contrast, the southern sites (Mattole River, Spanish Flat, and Shelter Cove) occupied areas lacking extensive rock formations; Spanish Flat and Shelter Cove currently have no recorded rookeries while the Mattole River has a small breeding area less than $200 \mathrm{~m}$ from shore. Falling between these two groups, the Gunther Island site was situated within the confines of Humboldt Bay, a large interior estuary. The distribution of terrestrial game follows a different but complementary pattern. Due to latitudinal differences in precipitation and rates of evapotranspiration, vegetation associations ranged from dense coniferous forest in the north (largely sitka spruce and redwood interspersed with prairie) to a more open and diverse mixture of Douglas fir, a variety of oaks, and some chaparral in the south. Because of these differences, terrestrial biomass was relatively low in the north, dominated by migratory herds of Roosevelt elk, while to the south, game was more abundant and diversified (dominated by dispersed resident populations of black-tail deer and a variety of other smaller game). In sum, the northern areas had resources concentrated in space and time, with high yields available from the ocean and relatively lower returns from the land. To the south, all resources were dispersed in time and space, and terrestrial habitats were more productive than marine habitats.

The following data are largely derived from Hildebrandt's (1981) work, augmented with information recently obtained by Levulett and Hildebrandt (1987) from Shelter Cove (HUM-307), Spanish Flat (HUM-276), 


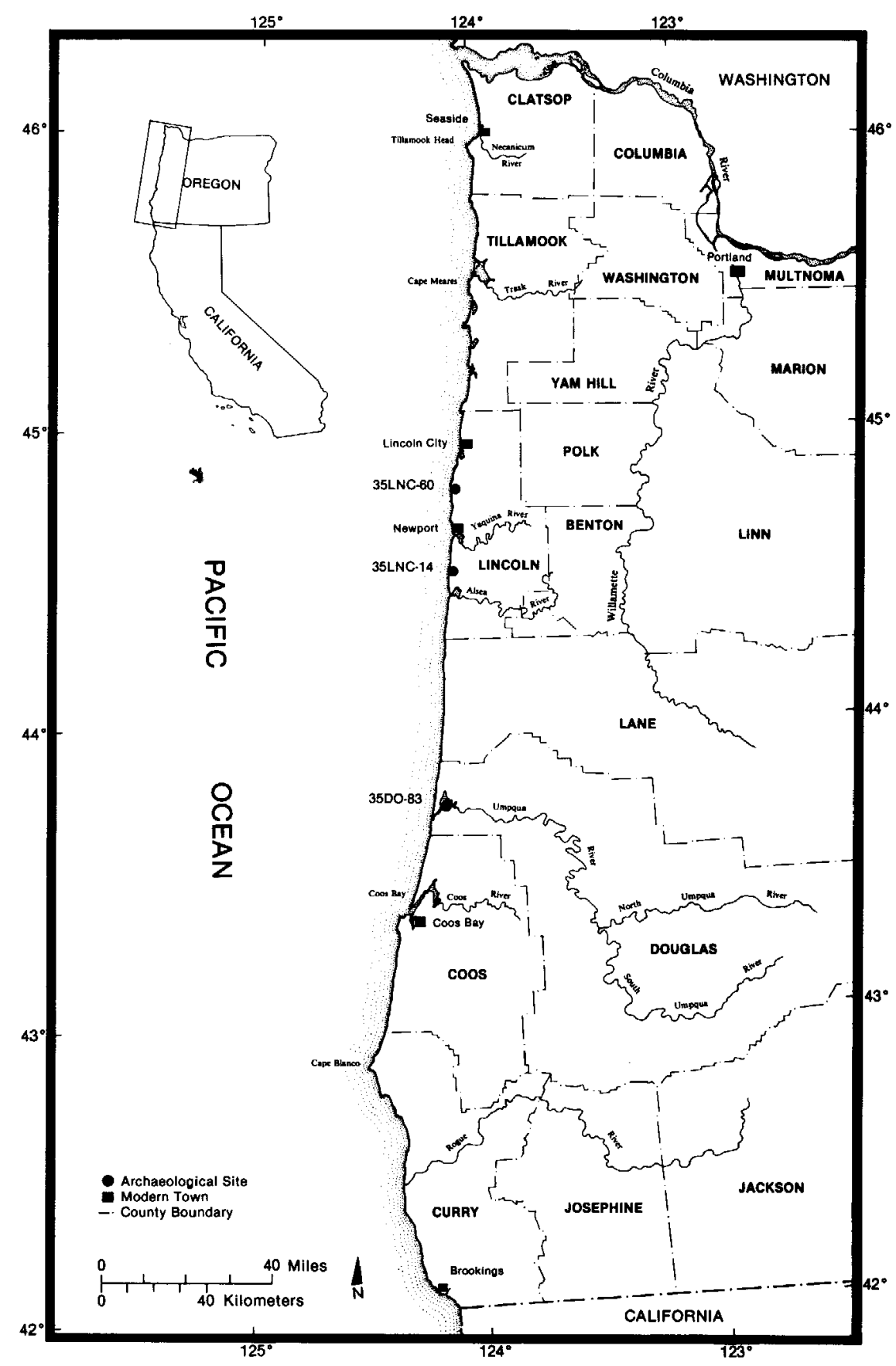

FIG. 1. Archaeological sites of the northern California coast yielding significant marine mammal assemblages. and Mattole River (HUM-175 and HUM-270). Additional corroborative data from White's (1988; n.d.) ongoing research on the Mendocino County coast are also examined.

Using the number of identified specimens (NISP), the northern group of sites exhibit a much higher percentage of marine versus terrestrial mammals, 71 to $29 \%$ (Table 1); of the terrestrial game, more elk than deer (66 to $34 \%$ ); and of the marine game, many more migratory breeders than resident species ( 82 to $18 \%$ ). A contrasting pattern is seen in the south, where terrestrial game is dominant (73 to $27 \%$ ); deer are much more abundant than elk (95 to 5\%); and of the meager sample of marine mammals, both resident and migratory species are present. Gunther Island, which lies within the large estuary of Humboldt Bay (lacking offshore rocks), produced results consistent with this pattern: a relatively low frequency of migratory taxa and an abundance of terrestrial game dominated by elk.

Although it is currently impossible to document the exploitation of breeding colonies with archaeofaunal age/sex data, since little such information is available, this conclusion is supported by the archaeological distribution of composite harpoon tips and ethnographic information regarding the use of ocean-going canoes (Table 2). The frequency of composite harpoon tips, which were mostly used to assist in the capture of pinnipeds at offshore rookeries, is highly correlated with the distribution of offshore rocks; one per $13 \mathrm{~m}^{3}$ of excavated midden in the north and one per $122 \mathrm{~m}^{3}$ in the south (a density difference of nearly 10 -fold). The ethnographic record also clearly identifies the use of ocean-going canoes in the north and the lack thereof to the south (Baumhoff 1958; Gould 1968; Heizer and Massey 1953; Hewes 1974; Kroeber 1922, 1925; Powers 1877).

Based on these relationships, Hildebrandt (1981) concluded that the combination of abundant offshore resources and reduced terrestrial game led northern groups to develop a technology capable of exploiting the former (i.e., ocean-going canoes). Construction, maintenance, and use of boats was only possible through organization of several laborers supported by reserve capital controlled only by a few headman:

\begin{abstract}
. . it was incumbent upon the man who wanted the canoe built that he provide his assistants with gifts of food while they worked for him. At times when additional labor was called for (for example, when the redwood log was hauled up out of the water, or when launching took place), the headman would call together all his relatives both affinal and consanguinal, to assist (in construction); usually the headman was the only person in the village who could afford to feed large numbers of people in this manner, so it is not surprising that only wealthy headmen owned such boats. (Gould 1968:16-17)
\end{abstract}

In addition to the ownership of canoes and other means of production, wealthy families of the Tolowa, Yurok, Hupa, and Wiyot could own 


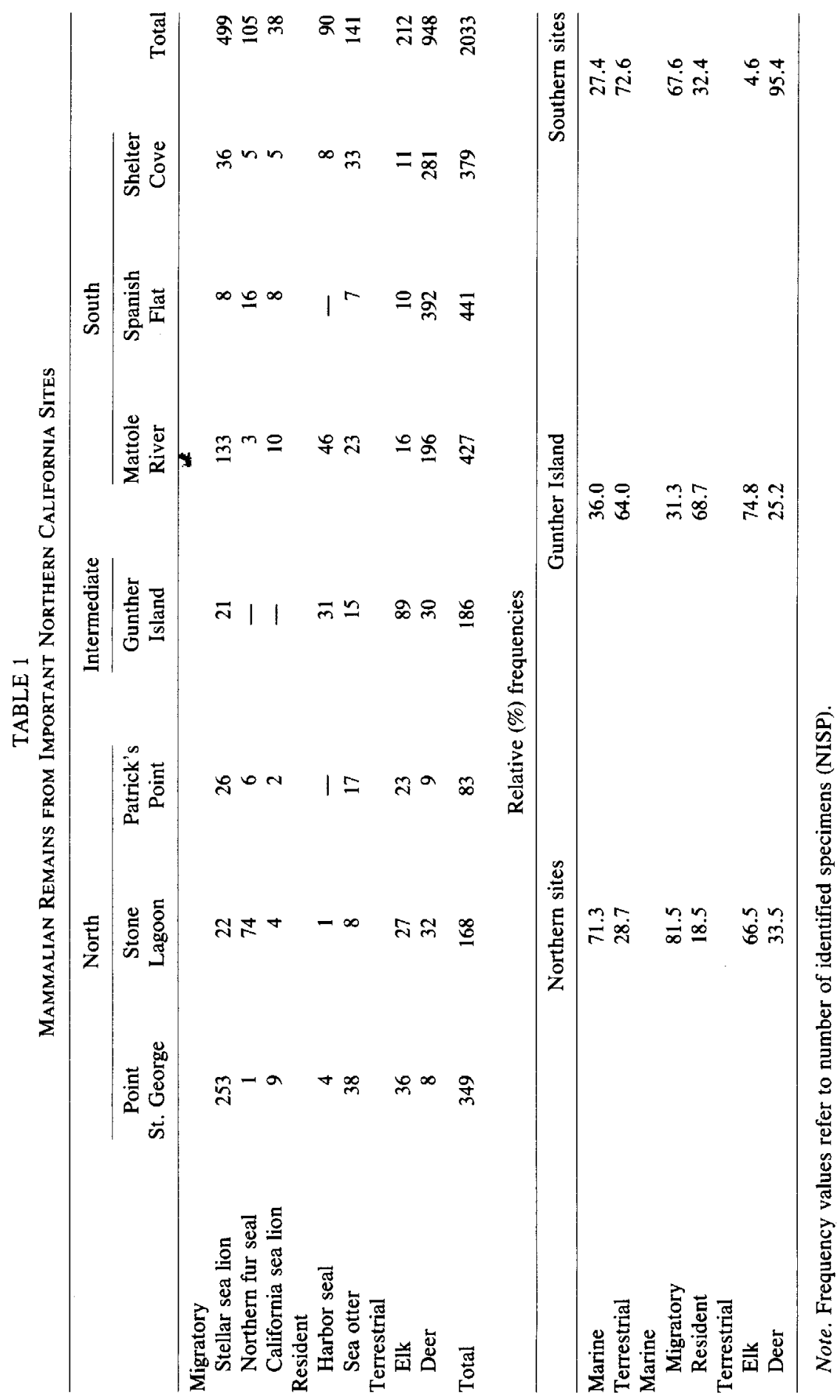

TABLE 2

Distribution of COMPOSITE HARPOON TIPS

\begin{tabular}{lccc}
\hline & Harpoons & $\begin{array}{c}\text { Excavated } \\
\text { volume }\end{array}$ & Frequency $/ \mathrm{m}^{\mathbf{3}}$ \\
\hline $\begin{array}{l}\text { Northern California } \\
\text { Northern sites }\end{array}$ & & \\
$\quad$ Point St. George & 17 & 275 & 0.06 \\
$\quad$ Stone Lagoon & 12 & 51 & 0.24 \\
Patrick's Point & 13 & 114 & 0.04 \\
$\quad$ Tsuari & 17 & 790 & 0.15 \\
Northern total & 59 & 100 & 0.07 \\
Gunther Island & 3 & & 0.03 \\
Southern sites & & 83 & \\
$\quad$ Mattole & - & 76 & $\mathrm{NA}$ \\
Spanish Flat & - & 245 & $\mathrm{NA}$ \\
$\quad$ Shelter Cove & 2 & & 0.03 \\
Southern total & & 115 & 0.01 \\
Oregon & 2 & 64 & \\
Umpqua/Eden & - & 130 & 0.02 \\
Whale Cove & 13 & & $\mathrm{NA}$ \\
Seal Rock & & & 0.10 \\
\hline
\end{tabular}

Note. Excavated volume expressed in cubic meters $\left(\mathrm{m}^{3}\right)$; Point St. George excavated volume based on profiles and maps in Gould (1966).

resource tracts such as acorn collecting groves, eddies for netting fish, and most importantly here, portions of offshore rookeries (Drucker 1937; Goddard 1903; Goldschimdt 1951; Kroeber 1925; Waterman 1920). In contrast, the terrestrial focus of the southern groups did not require the same kind of organization, and not surprisingly, the ethnographic record shows a lower degree of social stratification, not unlike that documented for most areas of central California (Elsasser 1978).

From Lyman's (1989) perspective, this scenario relies too heavily on historically recorded marine mammal behavior. Downplaying the interspecific differences in reproductive physiology and behavior outlined above, he argued the current lack of onshore rookeries was purely the result of historic sealing activities and that prior to the late 1800 s marine mammals of all kinds used the mainland for breeding. Following this argument, the archaeological presence of species currently breeding offshore tells us little about the methods used in their capture prehistorically. In support of this view, Lyman draws on apparent similarities between northern California assemblages associated with offshore rookeries and those from Oregon lacking offshore rocks but also dominated by migratory breeders. Although the presence of comparable assemblages from 
contrasting settings seems to support the argument that all marine mammal hunting took place on the mainland, it does not explain why the Tolowa and Yurok would travel $10 \mathrm{~km}$ on rough seas in dugout canoes to procure these animals when they could have been obtained without leaving the shore. In contrast to the expectations of Lyman, this technological innovation was fully in place prior to the impacts of historic sealing. For example, during the visit of Don Bruno de Hezeta to Yurok territory in 1775 , the expedition party was met by canoes each holding 28-30 individuals (Bodega Y Quadra 1865).

A closer examination of the Oregon data explains this apparent paradox (Fig. 2; Table 3). The first site dealt with by Lyman, Umpqua/Eden (35DO83), is similar to Gunther Island, lying within an estuary approximately $4.0 \mathrm{~km}$ from the ocean (Fig. 2). Irrespective of time, the marine mammal assemblage is dominated by resident species (principally harbor seal), and stop harpoon tips are relatively rare (Table 2 ). These findings are consistent with the northern California data cited above and, due to the estuarine setting of the site, have little bearing on the original issuethe prehistoric location of migratory breeder rookeries-since estuaries are not frequented by these animals. The second site, Seal Rock (35LNC14), has no distant offshore rocks, but there are numerous basalt stacks within $250 \mathrm{~m}$ of the shore (Lyman et al. 1988:81). Occupied only late in time, this site clearly documents exploitation of a Steller sea lion rookery. Although the adjacent rocks are not several miles out, the deposit did produce a relatively high frequency of stone harpoon tips. When comparing these data to the California sample, it seems likely that this nearshore rookery complex was exploited with the assistance of some kind of watercraft. Snyder, who did a preliminary analysis and interpretation of these materials, agrees:

Canoes, whether traded from the north or of local manufacture, were available and sufficiently seaworthy to transport hunters to the rookery rocks offshore. Harpoon heads similar to those in use among the Northwest groups appear to be a case of adoption of a cultural trait from outside the central Oregon coast and its subsequent adaptation by the indigenous. (Snyder 1978:82)

Similar to the rookeries off of Point St. George, Stone Lagoon, and Patrick's Point, the breeding colony at Seal Rock probably remained intact, due to the constraints associated with its exploration (i.e. transport with the use of watercraft).

The final and most important site, Whale Cove, 35LNC60, is located on the outer coast next to a series of onshore rocks (Fig. 2). Within the early component (1000-500 B.C.), migratory species dominate the marine mammal assemblage (69\%). Later (1400-1700 A.D.), however, resident marine taxa increase in frequency to the point of almost excluding the

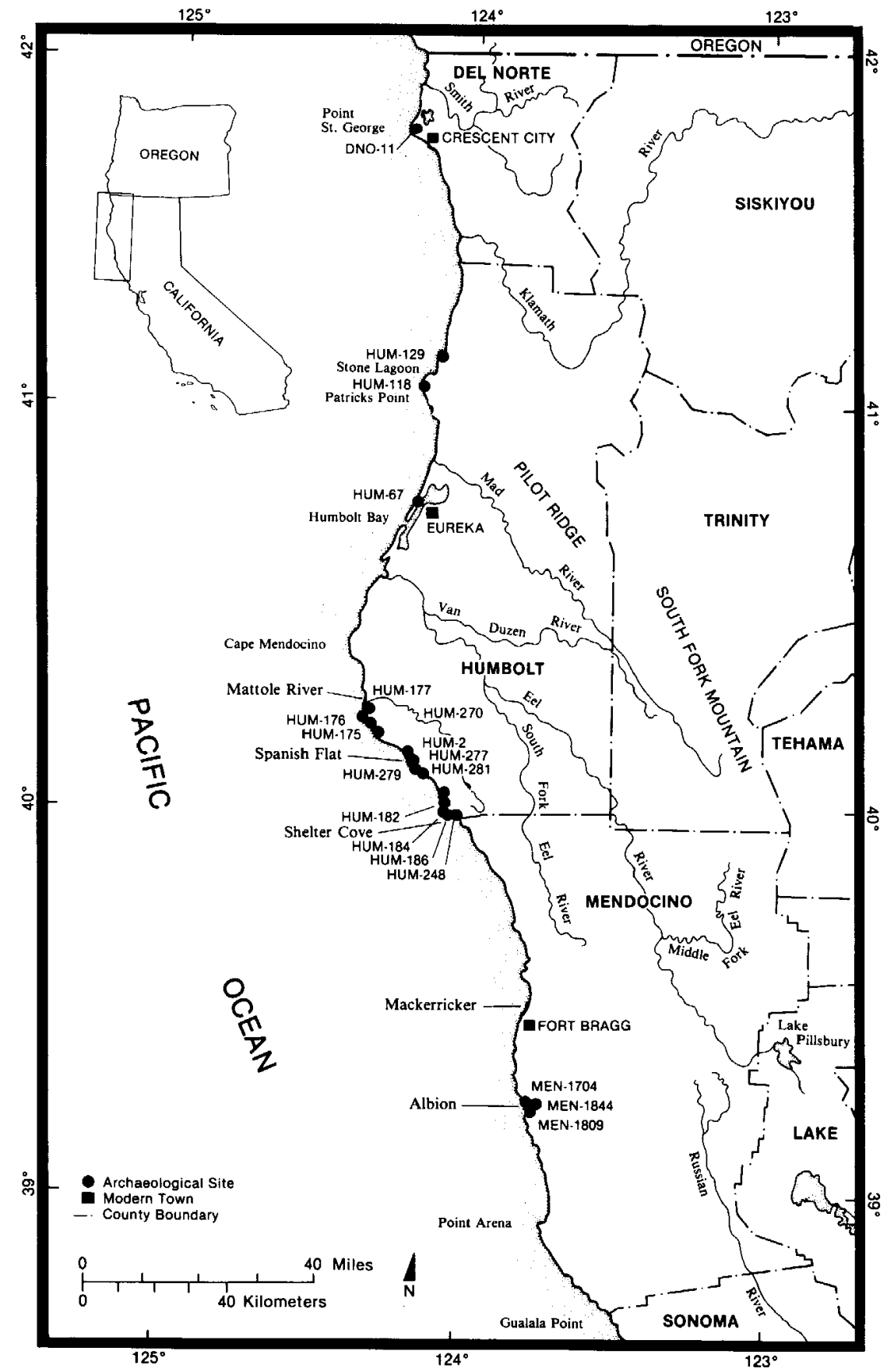

FIG. 2. Archaeological sites of the Oregon coast yielding significant marine mammal assemblages. 
TABLE 3

Mammalian Remains from Important Northern Oregon Sites

\begin{tabular}{|c|c|c|c|c|c|c|}
\hline & \multicolumn{2}{|c|}{ Umpqua/Eden } & \multicolumn{2}{|c|}{ Whale Cove } & \multirow[b]{2}{*}{$\begin{array}{c}\text { Seal Rock } \\
\text { Late } \\
\text { (1600- } \\
1900 \text { A.D.) }\end{array}$} & \multirow[b]{2}{*}{ Total } \\
\hline & $\begin{array}{c}\text { Early } \\
\text { (1000 B.C.- } \\
1000 \text { A.D.) }\end{array}$ & $\begin{array}{c}\text { Late } \\
(1100- \\
1800 \text { A.D. })\end{array}$ & $\begin{array}{c}\text { Early } \\
(1000- \\
500 \text { B.C. })\end{array}$ & $\begin{array}{c}\text { Late } \\
(1400- \\
1700 \text { A.D. })\end{array}$ & & \\
\hline \multicolumn{7}{|l|}{ Migratory } \\
\hline $\begin{array}{l}\text { sea lion } \\
\text { Northern }\end{array}$ & 4 & 23 & 19 & 3 & 986 & 1035 \\
\hline $\begin{array}{l}\text { Northern } \\
\text { fur seal }\end{array}$ & 14 & 17 & 19 & - & 97 & 147 \\
\hline California & & & & & & \\
\hline $\begin{array}{l}\text { sea lion } \\
\text { Resident }\end{array}$ & 2 & 7 & 4 & - & 31 & 44 \\
\hline Harbor seal & 159 & 269 & 11 & 67 & 33 & 539 \\
\hline Sea otter & 22 & 55 & 8 & 3 & 140 & 228 \\
\hline \multicolumn{7}{|l|}{ Terrestrial } \\
\hline Elk & 11 & 68 & 112 & 7 & 248 & 446 \\
\hline Deer & + 18 & 66 & 48 & 10 & 257 & 399 \\
\hline \multirow[t]{4}{*}{ Total } & 230 & 505 & 221 & 90 & 1792 & 2838 \\
\hline & \multicolumn{6}{|c|}{ Relative (\%) frequencies } \\
\hline & \multicolumn{2}{|c|}{ Umpqua/Eden } & \multicolumn{2}{|c|}{ Whale Cove } & Seal Rock & \\
\hline & Early & Late & Early & Late & Late & \\
\hline Marine & 79.7 & 73.5 & 27.6 & 81.1 & 71.8 & \\
\hline \multirow{2}{*}{\multicolumn{7}{|c|}{ Marine }} \\
\hline & & & & & & \\
\hline Migratory & 10.0 & 12.7 & 68.9 & 4.1 & 86.6 & \\
\hline Resident & 90.0 & 87.3 & 31.1 & 95.9 & 13.4 & \\
\hline \multicolumn{7}{|l|}{ Terrestrial } \\
\hline Elk & 37.9 & 50.7 & 70.0 & 41.2 & 49.1 & \\
\hline Deer & 62.1 & 49.3 & 30.0 & 58.8 & 50.9 & \\
\hline
\end{tabular}

Note. Frequency values refer to number of identified specimens (NISP).

others (migratory breeders drop from 69 to 4\%). Lacking harpoon tips in either component, this radical shift most likely indicates that migratory breeders formed rookeries on the mainland prior to significant aboriginal occupation of the coast. After being heavily exploited by pioneering hunters, rookeries shifted to more protected areas (such as offshore rocks), fostering major change in the local resource base, and requiring response on the part of the local human population. In northern California, peoples occupying areas lacking offshore rocks focused on terrestrial resources and the occasional marine mammal encounter. Those living near large offshore rookeries intensified their approach to marine hunting, developing sophisticated techniques to procure this obviously important resource. This explanation simultaneously accounts for Lyman's observations regarding the potential for prehistoric exploitation of mainland rookeries, and ethnographic descriptions of the Yurok and Tolowa traveling 10 $\mathrm{km}$ out to sea to hunt these animals.
Additional evidence of these diachronic trends comes from Mendocino County, where White (1988; n.d.) has investigated three sites situated on an open coast setting devoid of offshore rocks (Fig. 1). The earliest meaningful occupation occurred between 1 and 1000 A.D., and is dominated by Stellar sea lion and Roosevelt elk (Table 4). As expected, this initial abundance of sea lion (roughly $85 \%$ of the marine mammal assemblage) drops significantly during subsequent occupations, essentially being replaced by harbor seal and sea otters over time (Table 4). The predominance of resident marine mammals late in time is also found $40 \mathrm{~km}$ to the south at MEN-1704, -1809 , and -1844 (Fig. 1), where offshore rookeries are absent and harbor seal and sea otters make up $99.1 \%$ of the post-1000 A.D. marine mammal assemblage (Simons 1990).

\section{Central California}

Currently available archaeological data from central California suggest

TABLE 4

Mammalian Remains from Important Mendocino County Sites

\begin{tabular}{|c|c|c|c|}
\hline & $\begin{array}{c}\text { Early } \\
\text { (0-300 A.D.) }\end{array}$ & $\begin{array}{c}\text { Middle } \\
\text { (300-500 A.D.) }\end{array}$ & $\begin{array}{c}\text { Late } \\
\text { (1400-1840 A.D.) }\end{array}$ \\
\hline \multicolumn{4}{|l|}{ Migratory } \\
\hline Stellar sea lion & 171 & 5 & 1 \\
\hline Northern fur seal & 14 & - & - \\
\hline California sea lion & - & - & - \\
\hline Elephant seal & - & - & 1 \\
\hline \multicolumn{4}{|l|}{ Resident } \\
\hline Harbor seal & 6 & - & 70 \\
\hline Sea otter & 27 & 17 & 9 \\
\hline \multicolumn{4}{|l|}{ Terrestrial } \\
\hline Elk & 143 & 3 & 39 \\
\hline Deer & 102 & 40 & 24 \\
\hline \multirow[t]{3}{*}{ Total } & 463 & 65 & 143 \\
\hline & \multicolumn{3}{|c|}{ Relative (\%) frequencies } \\
\hline & Early & Middle & Late \\
\hline Marine & 47.1 & 33.8 & 55.9 \\
\hline Terrestrial & 52.9 & 66.2 & 44.1 \\
\hline \multicolumn{4}{|l|}{ Marine } \\
\hline Migratory & 84.9 & 22.7 & 1.3 \\
\hline Resident & 15.1 & 77.3 & 98.8 \\
\hline \multicolumn{4}{|l|}{ Terrestrial } \\
\hline Elk & 58.4 & 7.0 & 61.9 \\
\hline Deer & 41.6 & 93.0 & 38.1 \\
\hline
\end{tabular}

Note. Frequency values refer to number of identified specimens (NISP). 
significant variation in the timing of initial settlement of open and estuarine coasts (Fig. 3). The earliest humans to occupy this region apparently preferred estuaries and inland lacustrine environments to the open coast (T. Jones 1991). Human use of inland lakes is documented ca. 8000 B.C. at Tracy Lake (Heizer 1938), the Laguna Seca in Sonoma County (Origer and Fredrickson 1980), and SCR-177 in Santa Cruz County (Cartier 1988).

Use of estuaries ca. 7000-5000 B.C. is suggested by findings from Bodega Bay (Fredrickson 1984; Schwaderer et al. 1990) and Elkhorn Slough (Dietz et al. 1988). The earliest known shell middens on San Francisco Bay date ca. 2000 B.C., but earlier sites have most likely been lost to sea-level transgression, which had particularly extensive effects in this locale (Bickel 1978). Heavy use of the outer coast begins ca. 3500-2500 B.C. as represented by a number of sites on the Santa Cruz and Monterey County coastline (Breschini and Haversat 1980, 1989; Cartier 1984; Dietz and Jackson 1981 D. Jones and Hildebrandt 1990). This early open coast settlement shows a high reliance on marine resources, which gradually, yet significantly lessens through time. Estuarine settings show a similar pattern. At the onset of the Late Period (ca. 1000 A.D.) many residential bases in both settings appear to have been abandoned (T. Jones 1989a). Marine resources continued to be exploited, but through the use of coastal camps and specialized processing sites, with major residential bases located inland. This settlement shift seems to reflect an intensified focus on interior oak woodland resources, particularly the acorn (T. Jones 1989a, 1989b:55). In general prehistoric occupation of the central coast can be divided into four periods: before 3500 B.C., 3500-500 B.C., 500 B.C-1000 A.D, and 1000 A.D.-Contact.

Outer coast. Because estuaries are infrequently visited by migratory breeders (Orr and Helm 1989:69), patterns of human predation on the outer coast are likely to be more telling with respect to human destruction of mainland rookeries. Outer coast data are available from Hylkema (1991) and Clark (1986) for San Mateo County, and Breschini and Haversat (1989), Hildebrandt and Hall (n.d.), Gifford and Marshall (1984), T. Jones (1988, n.d.), and Simons (1981) for Monterey Bay and the Big Sur coast (Fig. 3).

Hylkema (1991) reported four outer coast sites (SMA-97, -115, -118, and -218 ) representing the 3500-500 B.C. and 1000 A.D.-Contact intervals, while Clark provides data from SMA-72, a single component site postdating 1000 A.D. Situated on a coastline lacking distant offshore rocks, the early San Mateo components show a predominance $(90 \%)$ of migratory taxa (principally northern fur seal) relative to other marine mammals, whereas the reverse is the case late in time, in which sea otter and harbor seal are both abundant (Table 5). Data from Monterey Bay are slightly more complicated, judging from faunal samples available from

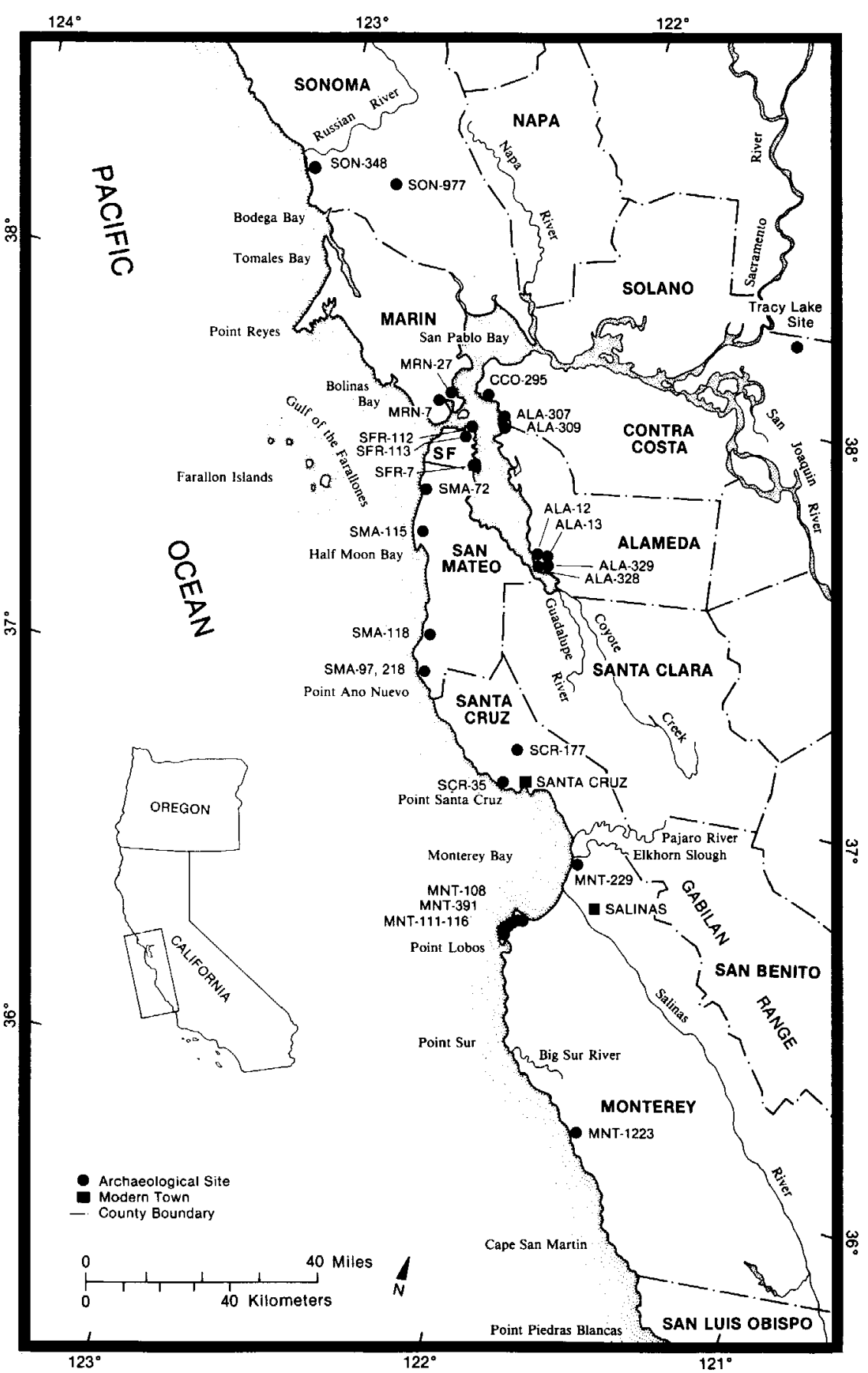

FIG. 3. Selected archaeological sites of the central California coast yielding significant vertebrate faunal assemblages. 
TABLE 5

Mammalian Remains from Important Central California Sites

\begin{tabular}{|c|c|c|c|c|c|}
\hline & \multicolumn{2}{|c|}{ San Mateo } & \multicolumn{3}{|c|}{ Monterey } \\
\hline & $\begin{array}{c}\text { Early } \\
(1000- \\
500 \text { B.C. })\end{array}$ & $\begin{array}{c}\text { Late } \\
(1000- \\
\text { Contact })\end{array}$ & $\begin{array}{c}\text { Early } \\
(3000- \\
500 \text { B.C.) }\end{array}$ & $\begin{array}{c}\text { Middle } \\
\text { (500 B.C.- } \\
1000 \text { A.D.) }\end{array}$ & $\begin{array}{c}\text { Late } \\
\text { (1000 A.D.- } \\
\text { Contact) }\end{array}$ \\
\hline \multicolumn{6}{|l|}{ Migratory } \\
\hline Stellar sea lion & - & 3 & 1 & 2 & 3 \\
\hline Northern fur seal & 142 & 28 & 52 & 65 & 5 \\
\hline California sea lion & - & 15 & 7 & 2 & 2 \\
\hline Elephant seal & - & - & - & - & - \\
\hline \multicolumn{6}{|l|}{ Resident } \\
\hline Harbor seal & 1 & 89 & 1 & 11 & 1 \\
\hline \multirow{2}{*}{\multicolumn{6}{|c|}{ Terrestrial }} \\
\hline & & & & & \\
\hline Elk & 1 & 19 & 3 & 2 & 7 \\
\hline Deer & 20 & 77 & 20 & 64 & 128 \\
\hline Total & 169 & 910 & 125 & 158 & 154 \\
\hline \multicolumn{6}{|c|}{ Relative (\%) frequencies } \\
\hline & \multicolumn{2}{|c|}{ San Mateo } & \multicolumn{3}{|c|}{ Monterey } \\
\hline & $\begin{array}{c}\text { Early } \\
(1000- \\
500 \text { B.C. })\end{array}$ & $\begin{array}{c}\text { Late } \\
\text { (1000- } \\
\text { Contact) }\end{array}$ & $\begin{array}{c}\text { Early } \\
(3000- \\
500 \text { B.C. })\end{array}$ & $\begin{array}{l}\text { Middle } \\
\text { (500 B.C.- } \\
1000 \text { A.D.) }\end{array}$ & $\begin{array}{c}\text { Late } \\
\text { (1000 A.D.- } \\
\text { Contact) }\end{array}$ \\
\hline Marine & 87.6 & 89.5 & 81.6 & 58.2 & 12.3 \\
\hline Terrestrial & 12.4 & 10.5 & 18.4 & 41.8 & 87.7 \\
\hline \multicolumn{6}{|l|}{ Marine } \\
\hline Migratory & 95.9 & 5.7 & 58.8 & 75.0 & 52.6 \\
\hline Resident & 4.1 & 94.3 & 41.2 & 25.0 & 47.4 \\
\hline \multicolumn{6}{|l|}{ Terrestrial } \\
\hline Elk & 4.8 & 19.8 & 13.0 & 3.0 & 21.2 \\
\hline Deer & 95.2 & 80.2 & 87.0 & 97.0 & 78.8 \\
\hline
\end{tabular}

Note. Frequency values refer to number of identified specimens (NISP).

MNT-108 (Breschini and Haversat 1989), MNT-111, -112, -113, -114, -115, -116 (Simons 1981), MNT-391 (Hildebrandt and Hall n.d.), MNT1223 (T. Jones 1988, n.d.) and SCR-35 (Gifford and Marshall 1984). Together, these 10 sites represent all 5500 years of known human occupation of the outer coast of central California, and exhibit now-familiar patterns: Early and Middle Period occupation is marked by high proportions of migratory breeders (primarily northern fur seal), whereas the Late Period is marked by a dramatic decrease in fur seal, a migratory breeder, and a concomitant increase in resident sea otter and harbor seal (Table 5). The proportion of migratory breeders is higher (52.6\%) in Late Period assemblages than elsewhere, but marine taxa of any kind are quite rare in the overall mammalian sample (12.3\%), a trend correlating with the increased attention given to terrestrial environments at the end of the Middle Period. Indeed, a partial explanation for this increased terrestrial focus may lie in the decreased productivity of the nearshore environment as a result of the elimination of mainland rookeries. In the absence of offshore rocks, migratory breeders simply ceased to be available in this region in significant numbers.

Estuarine coast. The central California coast is also marked by series of estuarine systems, the largest being San Francisco Bay (Fig. 3). Smaller systems are found at Tomales Bay, Bodega Bay, and Elkhorn Slough. The latter two locations have produced the oldest coastal archeofaunas from central California. A component dating ca. 7000-6000 B.C. has recently been reported from SON-348 at Bodega Bay (Schwaderer et al. 1990). Analysis of faunal remains from this location is not yet complete, but fur seal remains are present (D. Simons, personal communication 1991). A component dating ca. 5000-4000 B.C. from MNT-229 at Elkhorn Slough produced remains of northern and southern fur seals, and California and Steller sea lions (Table 6), however marine mammals do not constitute a major portion of the mammalian assemblage (30.1\%), nor do migratory breeders $(25 \%)$ dominate over residents $(75 \%)$. This pattern

TABLE 6

Mammalian Remains from Elkhorn Slough (MNT-229)

\begin{tabular}{|c|c|c|}
\hline & $\begin{array}{c}\text { Early } \\
\text { (Pre-3500 B.C.) }\end{array}$ & $\begin{array}{c}\text { Middle } \\
\text { (500 B.C. }-1000 \text { A.D.) }\end{array}$ \\
\hline \multicolumn{3}{|l|}{ Migratory } \\
\hline Sea lion & 2 & 16 \\
\hline Fur seal & 5 & 13 \\
\hline Elephant seal & - & - \\
\hline \multicolumn{3}{|l|}{ Resident } \\
\hline Harbor seal & 4 & 48 \\
\hline Sea otter & 17 & 90 \\
\hline Elk & 11 & 84 \\
\hline Deer & 54 & 349 \\
\hline \multirow[t]{3}{*}{ Total } & 93 & 600 \\
\hline & \multicolumn{2}{|c|}{ Relative $(\%)$ frequencies } \\
\hline & $\begin{array}{c}\text { Early } \\
\text { (Pre-3500 B.C.) }\end{array}$ & $\begin{array}{c}\text { Middle } \\
\text { (500 B.C. }-1000 \text { A.D.) }\end{array}$ \\
\hline Marine & 30.1 & 20.8 \\
\hline Terrestrial & 69.9 & 79.2 \\
\hline \multicolumn{3}{|l|}{ Marine } \\
\hline Migratory & 25.0 & 25.4 \\
\hline Resident & 75.0 & 74.6 \\
\hline \multicolumn{3}{|l|}{ Terrestrial } \\
\hline Elk & 16.9 & 19.4 \\
\hline Deer & 83.1 & 80.6 \\
\hline
\end{tabular}

Note. Frequency values refer to number of identified specimens (NISP). 
remains virtually unchanged through later site occupation during the Middle Period (500 B.C.-1000 A.D.).

More substantial estuarine archaeofaunas are reported from San Francisco Bay (Cope 1985; Simons 1991). Here too, there is little change with time (Fig. 3; Table 7). The earliest occupation (3500-500 B.C.) is represented almost exclusively by the lower component at ALA-307 (Wallace and Lathrap 1975), which shows migratory breeders representing $21.4 \%$ of the marine mammal assemblage. Middle Period (500 B.C.-1000 A.D.) assemblages are available from ALA-12 (Watts 1984), ALA-307 (Busby 1975), ALA-328 (lower component) (Bickel 1981; Watts 1984), CCO-295 (Banks and Orlins 1981), SFR-7 (McCrossin 1982), SFR-112 (Pastron and Walsh 1988a), and SFR-113 (Pastron and Walsh 1988b). These sites suggest relatively minor increases in the exploitation of marine taxa $(47.5 \%)$ and resident breeders $(88.3 \%)$, both figures reflecting intensified exploi-

TABLE 7

Mammalian Remains from Important San Francisco Bay Sites

\begin{tabular}{|c|c|c|c|c|}
\hline & $\begin{array}{c}\text { Early } \\
(2500- \\
500 \text { B.C. })\end{array}$ & $\begin{array}{c}\text { Middle } \\
\text { (500 B.C.- } \\
1000 \text { A.D.) }\end{array}$ & $\begin{array}{c}\text { Late } \\
\text { (1000 A.D.- } \\
\text { Contact) }\end{array}$ & Total \\
\hline \multicolumn{5}{|l|}{ Migratory } \\
\hline Sea lion & 3 & 604 & 11 & 618 \\
\hline Fur seal & 0 & 23 & 0 & 23 \\
\hline \multicolumn{5}{|l|}{ Resident } \\
\hline Harbor seal & 8 & 346 & 175 & 529 \\
\hline Sea otter & 3 & 4390 & 1026 & 5419 \\
\hline Elk & 0 & 1102 & 67 & 1169 \\
\hline Deer & 22 & 4803 & 505 & 5330 \\
\hline Pronghorn & 0 & 11 & 46 & 57 \\
\hline \multirow[t]{3}{*}{ Total } & 36 & 11279 & 1830 & 13145 \\
\hline & \multicolumn{3}{|c|}{ Relative $(\%)$ frequencies } & \\
\hline & $\begin{array}{c}\text { Early } \\
(2500- \\
500 \text { B.C. })\end{array}$ & $\begin{array}{c}\text { Middle } \\
\text { (500 B.C.- } \\
1000 \text { A.D.) }\end{array}$ & $\begin{array}{c}\text { Late } \\
\text { (1000 A.D.- } \\
\text { Contact) }\end{array}$ & \\
\hline Marine & 39.0 & 47.5 & 66.3 & \\
\hline Terrestrial & 61.0 & 52.5 & 33.7 & \\
\hline \multicolumn{5}{|l|}{ Marine } \\
\hline Migratory & 21.4 & 11.7 & 0.9 & \\
\hline Resident & 78.6 & 88.3 & 99.1 & \\
\hline \multicolumn{5}{|l|}{ Terrestrial } \\
\hline Elk & 0 & 18.6 & 10.8 & \\
\hline Deer & 100 & 81.2 & 81.7 & \\
\hline Pronghorn & 0 & 0.2 & 7.5 & \\
\hline
\end{tabular}

Note. Frequency values refer to number of identified specimens (NISP). tation of the sea otter, which alone constitute $39 \%$ of San Francisco Bay Middle Period assemblages. This trend continues into the Late Period, when, based on materials from ALA-328, ALA-329 (Watts 1984), and MRN-17 (Simons 1991), exploitation of marine taxa increases to $66.3 \%$, almost all of that being resident breeders (99.1\%). Migratory breeders were never of economic importance within San Francisco Bay, but their complete absence among Late Period assemblages may reflect decreased availability through time, similar to diachronic patterns evident on the outer coast. While the human exploitative impact on pinniped populations in central coast estuaries was not as great as that on the open coast, it nonetheless contributed to the overall predatory pressure experienced by these species. Ever-growing human populations resorted to the exploitation of more elusive resident marine mammals in San Francisco Bay, and terrestrial taxa on the open coast, in order to compensate for the decreasing yields of large pinnipeds.

\section{Southern California}

The southern California coast is important to understanding the ecological interface between prehistoric seals and sea lions, and humans because historic accounts (Scammon 1874) and available archaeological data (Walker and Craig 1979) suggest that breeding colonies of all six northeastern Pacific pinniped taxa have been present on the Channel Islands into remote antiquity. The open coast of northern Santa Barbara and San Luis Obispo counties (Fig. 4) also provides abundant haulout sites for sea lions and harbor seals (Bonnell et al. 1983:4), but little is known about the use of these habitats in prehistory.

The currently available record makes clear that settlement of marine habitats began very early in southern California. Initial occupation began ca. 8000-6500 B.C., and included settlement of estuaries, open coasts, and islands. Subsequent habitation can be divided into four periods: 6500 3500 B.C., 3500-1000 B.C., 1000 B.C. -1000 A.D., and 1000 A.D.Contact.

Following initial settlement, the number of sites occupied in this region increases dramatically between 6500 and 3500 B.C., with a concomitant diversification in site locations. Marked by artifact assemblages in which millingstones are predominant, sites dating to this interval have been identified on the bluffs overlooking San Diego estuaries, on the rocky and protected shores of the Santa Barbara Channel, and at many inland locations. Along the Santa Barbara Channel, Rogers (1929:343) found that Millingstone Period sites were located almost exclusively inland, in association with oak groves. Later researchers have confirmed this pattern (C. King 1982:149; Glassow et al. 1988:68), although radiocarbon dates doc- 


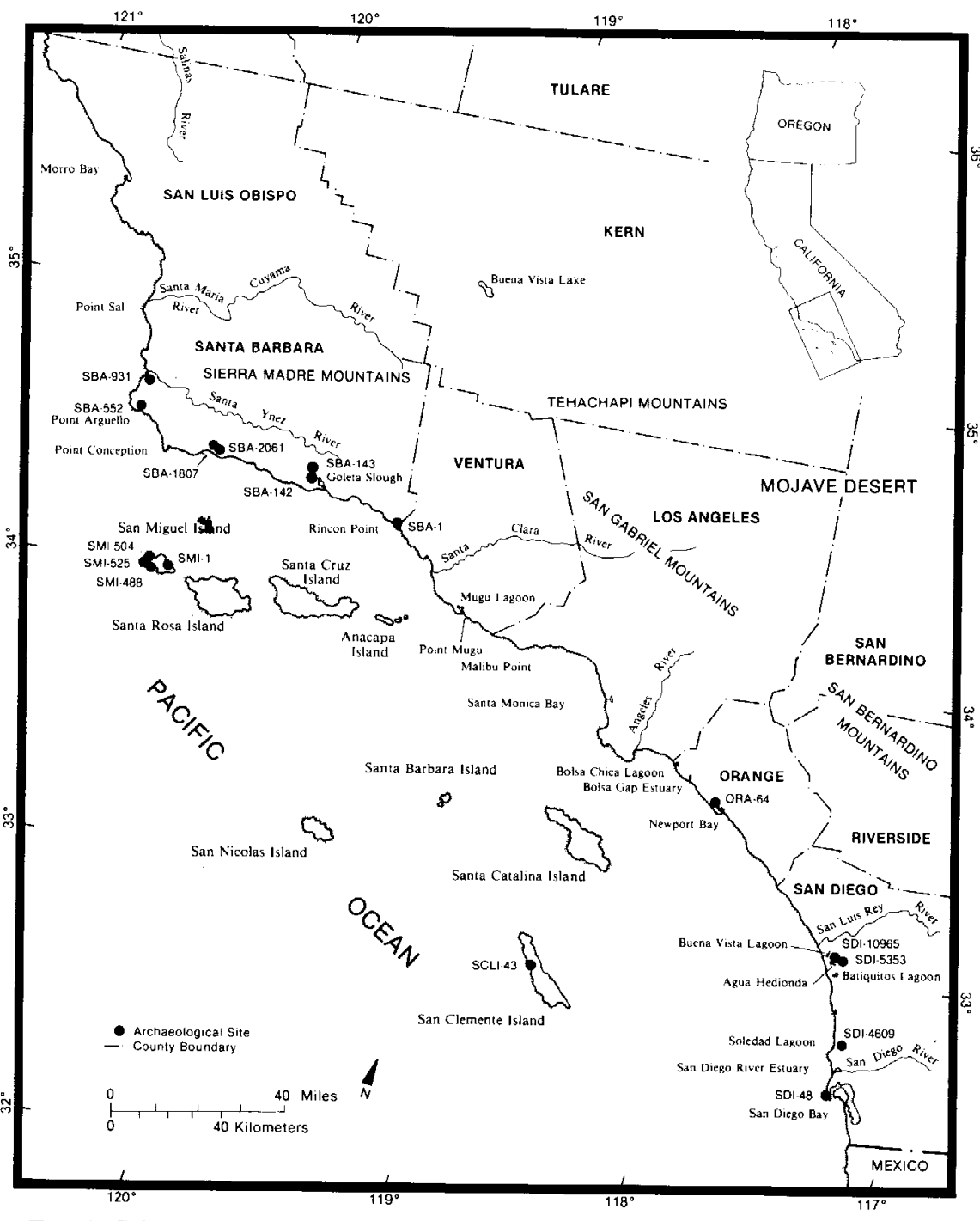

FIG. 4. Selected archaeological sites of the southern California coast yielding significant vertebrate faunal assemblages.

ument contemporaneous use of shoreline settings as well. A similar pattern has been recognized in San Diego County (Warren et al. 1961:24). Colten (1987:71) suggests that the settlement strategy represented by this pattern was one of low logistical, but high residential mobility (e.g., a forager pattern).

Generalizations about the south coast become difficult after 3500 B.C. due to increased geographic variation. In the Santa Barbara area, major technological innovation (i.e., appearance of the mortar and pestle) is attributed to population stress caused by increasing human numbers and decreased biotic productivity associated with mid-Holocene warming (Glassow et al. 1988). On the San Diego coast, however, this period does not differ markedly from the preceding one (Wallace 1955; True 1966; Warren 1968). In both areas use of all types of coastal and inland environments continues.

Sites continue to increase and appear in more diverse settings after 1000 B.C. except in San Diego and Orange counties, where estuarine habitation decreases. Abandonment of estuarine settings at this time was first recognized by Warren and Pavesic (1963) at Batiquitos Lagoon and has recently been reconfirmed by Gallegos (1987) at that location, as well as in other similar contexts (Macko and Mason 1990). It is generally attributed to siltation of coastal lagoons. Plank canoes well suited to marine use appear in the Santa Barbara Channel toward the end of this period (C. King 1982:357) and represent a costly yet significant improvement over earlier watercraft.

The Late Period (post-1000 A.D.) shows a still greater profusion of sites on the south coast, including continued use of all types of marine habitats. In the Santa Barbara area this period is marked by large permanent shoreline villages (C. King 1982:151), with extensive commerce between the islands and the mainland. Sophisticated extractive technologies are evident in the Santa Barbara Channel at this time in the form of finely made shell and bone fishhooks, elaborate compound bone hooks, and compound harpoon points (C. King 1981:357). Sedentary life was apparently accomplished through intensive exploitation of marine foods in conjunction with heavy reliance on acorn storage.

Changes in settlement and subsistence accompanying the transition from the Middle to Late Period further south show no comparable focus on marine resources. While some (Shipek 1977, 1982; Hector 1984; Oxendine 1983) argue for sedentism, the empirical record is more suggestive of seasonal transhumance (Quintero 1987) with minimal use of marine resources (Christenson 1991).

Mainland exposed coast. Pinniped remains have been identified among the oldest faunal assemblages in this region, but evidence for the exploitation of mainland rookeries is limited. Only the Ballast Point site (SDI48) in San Diego County, produced abundant marine mammal remains dating ca. 4600 B.C. (Gallegos and Kyle 1988:8-32). Identified taxa included sea otter, California sea lion, southern fur seal, and harbor seals, but the inordinately high frequency of California sea lion remains was considered indicative of the presence of a now-extinct rookery (Gallegos and Kyle 1988:8-38). The abundance of predator-free island shoreline in 
this region, particularly within the Santa Barbara Channel, would have obviated the need to establish mainland breeding colonies, and a general absence of pinniped remains in mainland contexts is to be expected. Indeed, at SBA-1807 (Fig. 4), dating ca. 6700 B.C., Erlandson (1988:171) found that sea mammals constituted only $1.2 \%$ of the vertebrate assemblage. At SBA-931a, dating ca. 7000 B.C., situated on the remote Point Arguello headland, Glassow (1991) reported sea mammal remains representing $55.2 \%$ of the protein consumed by site inhabitants; however, this frequency is attributed to common usage of this shoreline for hauling out (Glassow 1990). Later mainland assemblages, including those from SBA-1 (Peterson 1984), -552 (Glassow 1990), -2057 and -2061 (Erlandson 1988) fail to show frequencies of pinniped elements indicative of the presence of rookeries.

Island shoreline. In the absence of mainland rookeries it is not surprising that the oldest occupations on the Channel Islands are associated with pinniped exploitation. On San Clemente Island, the oldest component at SCLI-43b (ca. 7000 B.C.) contained seal and sea lion remains (Roy Salls, personal communication 1991). More significantly, Goldberg (1989:27) reported stable isotope analysis of human bone collagen samples from this same component suggesting a diet "composed almost entirely of marine mammals."

More substantial marine mammal remains have been reported from San Miguel Island sites SMI-1 (Billman and Walker 1990), SMI-525 (Walker and Craig 1979), and SMI-488 and SMI-504 (Walker and Snethkamp 1984). While dating is somewhat tenuous at these locations, the early component at SMI-1 (6500-3500 B.C.) produced an assemblage dominated by migratory breeders $(82.0 \%)$, over $70 \%$ of these being fur seal (Table 8). The later component at this location (ca. 3500-1000 B.C.) manifests significant, predictable change: fur seals decrease (73.6 to $44.0 \%$ ), sea otters increase (13.6 to $42.0 \%$ ), and the overall proportion of resident species more than doubles (18.0 to $50.0 \%$ ). Billman and Walker (1990) also noticed an overall decrease in the frequency of marine mammal remains through time at the site, but attributed it to reduced marine productivity associated with mid-Holocene warming: elevated sea temperatures are believed to have destroyed local kelp forests, reducing fish populations, thereby decreasing the amount of food available to seals and sea lions, whose populations declined as a consequence. Given the universal decline of migratory breeders in other settings with different climatic and upwelling regimes, human predation seems a more reasonable, simpler explanation for this diachronic reduction in frequency.

Unlike the prehistoric mainland rookeries of California and Oregon, breeding colonies on San Miguel Island did not disappear entirely, but continued to exist and be exploited by aboriginal populations. Site SMI-
TABLE 8

Mammalian Remains from Important Sites on San Miguel Island

\begin{tabular}{|c|c|c|c|c|}
\hline & $\begin{array}{c}\text { SMI-1 } \\
(6500- \\
3500 \text { B.C. })\end{array}$ & $\begin{array}{c}\text { SMI-1 } \\
(3500- \\
1000 \text { B.C. })\end{array}$ & $\begin{array}{l}\text { SMI-525 } \\
(1000 \text { B.C.- } \\
\text { A.D. 1200) }\end{array}$ & $\begin{array}{c}\text { SMI-488-50 } \\
\text { (post } 1200 \text { A.D.) }\end{array}$ \\
\hline \multicolumn{5}{|l|}{ Migratory } \\
\hline Sea lion & 25 & 5 & 31 & 20 \\
\hline Fur seal & 217 & 37 & 50 & - \\
\hline Elephant seal & - & - & 11 & - \\
\hline \multicolumn{5}{|l|}{ Resident } \\
\hline Harbor seal & 13 & 6 & 9 & 2 \\
\hline Sea otter & 40 & 36 & 26 & 26 \\
\hline Total & 295 & 84 & 127 & 48 \\
\hline Migratory (\%) & 82.0 & 50.0 & 72.4 & 41.6 \\
\hline Resident $(\%)$ & 18.0 & 50.0 & 27.6 & 58.4 \\
\hline
\end{tabular}

Note. Frequency values refer to number of identified specimens (NISP).

525 , dating approximately 1000 B.C. -1200 A.D., shows a higher frequency of migratory breeders than evidenced during the preceding period (72.4 as opposed to $50.0 \%$ ), represented by significant numbers of both fur seals and sea lions (Table 8). After 1200 A.D., fur seals disappear all together and the frequency of resident species increases to an all-time high $(58.4 \%)$. This latter shift has been attributed to the impact of aboriginal hunters, who accelerated the demise of fur seal populations by selectively removing their forelimbs for ease of transport overland and to limit the use of cargo space within the plank canoes (Walker and Snethkamp 1984). Preferential transport of forelimbs is documented at mainland sites, where forelimb elements are over-represented in late period assemblages (Lyon 1937).

Diachronic patterning in marine mammal assemblages is thus different on the Channel Islands, as well might be expected, given that these settings, particularly the more remote islands, have been subject to less constant human occupation. They also represent the last remaining option for refuge by migratory breeders; there simply was nowhere left to go. The initial impacts of humans on the islands must have been severe, but never so great as those inflicted on the mainland. Early peoples established temporary living sites on the islands and thus were not constrained by the exorbitant costs associated with transport. As a consequence, fur seal populations were initially reduced in concert with a heavy focus on these animals. By 1000 B.C., the proportion of residents among the marine mammal assemblage more than doubled (from 18 to 50\%); this trend, however, is then succeeded by an apparent resurgence of the migratory 
breeder population, although frequencies never return to the levels associated with initial occupation (Table 8). With low human numbers and only sporadic use of the more remote islands, renewal of the seal populations is consistent with optimal foraging principles, in that pursuit of these taxa to complete annihilation would encumber significantly suboptimal procurement behaviors. Later in time, after development of the plank canoe and more permanent island settlement, transport costs to the mainland were reduced and the fur seal rookeries were affected again. Owing to the tremendous number and diverse settings of breeding populations on the islands, however, aboriginal impacts were still not severe enough for these species to have been extirpated.

Estuarine coast. As elsewhere, south coast sites associated with estuaries manifest lower frequencies of seal and sea lion remains and little change over time. At ORA-64, dating ca. 6400-3600 B.C., pinniped bones represent only $5 \%$ of the vertebrate remains (Koerper 1981:378). California sea lion and sea otter are present at SBA-143, but constitute no more than a small percentage of the vertebrate fauna (Colten 1987:52). Seals and sea lions were likewise identified at nearby SBA-142 (Owen et al. 1964:464), where their proportion was somewhat higher (roughly 35\%). Early estuarine sites in San Diego County, such as SDI-10965 (Gallegos and Carrico 1984) and SDI-4609 (Carrico and Taylor 1983) contain virtually no marine mammal remains. Late sites exhibit an overwhelming reliance on small terrestrial game reflecting the deterioration of local estuarine systems; SDI-5353 on Agua Hedionda Lagoon, for example, yielded a vertebrate assemblage containing 1539 rabbit elements, 16 of deer, compared with only 3 of otter, and 4 of sea lion (Koerper 1986).

\section{SUMMARY AND DISCUSSION}

The open coast of California and Oregon was initially occupied at divergent points in time, but early inhabitants universally encountered sea lion and fur seal rookeries. Easily accessible to terrestrial hunters, these hypothetical mainland breeding colonies were exploited so heavily that they were eliminated relatively quickly, leaving offshore contexts as the only viable sites for continued breeding. Coastal areas lacking offshore rocks or islands were essentially left with resident populations of harbor seal and sea otter, who could reproduce without forming long-term, nonaquatic breeding colonies. Under such circumstances, terrestrial resources tended to become the major focus of intensification. In most of northern California (Mattole River, Spanish Flat, Shelter Cove, Mendocino, Albion), central California (San Mateo, San Francisco Bay, Monterey Bay), and southernmost California (San Diego County sites), sedentary villages never appeared on the coast. Rather, in central California and southernmost northern California, permanent residential bases were situated next to interior salmon streams and acorn groves, while in southernmost California (San Diego County) a more mobile transhuman adaptation was maintained.

In areas where offshore rocks and/or islands were present (principally the northernmost coast of California and the Santa Barbara Channel), local inhabitants intensified their approach to marine mammal hunting through the development of watercraft. Although this innovation allowed access to the vulnerable offshore rookeries, breeding populations appear to have maintained themselves because of the high pursuit and transport costs associated with marine travel.

In contrast to those areas lacking offshore rocks and islands, sedentary villages were common along northwest California and the Santa Barbara Channel. Marine resources from offshore contexts played a major role in the overall economy, but sedentary life was largely dependent on the storage of acorns and dried fish. A great deal of time and energy was invested in the construction, maintenance, and use of both the large dugout canoe of the Northwest and the plank canoe of the Channel. Because of their size in the north (up to $40 \mathrm{ft}$ in length and $10 \mathrm{ft}$ in beam), and complex design in the south, construction costs were quite high and financed only by wealthy headmen who in turn controlled/owned the resources obtained during offshore forays. Combined with other capital intensive pursuits such as construction of salmon weirs, smoke houses, and large residential structures, the organizational requirements of canoe use no doubt contributed to the high degree of social stratification exhibited by the aboriginal peoples in both of these locations.

The emergence of ranked society among the Chumash has been discussed by C. King (1982, 1990), Martz (1984), and most importantly, by L. King (1982), who posits a direct link between the presence of a "chiefdom type" political organization and canoes, in that ownership of canoes allowed elites to exploit other community members by controlling trade. Most recently Arnold (1990) has combined a similar neo-Marxist perspective with ecological theory to argue that the development of a stratified hunter-gatherer society in the Santa Barbara Channel was largely the result of historical accident; as a response to a major environmental catastrophe (e.g., a 100-year period of extremely elevated seawater temperatures beginning at the end of the Middle Period ca. 1150 A.D.), social stratification and craft specialization arose, as elites conspired to obtain economic power in the face of crisis. We concur with $L$. King (1982) that a more significant step toward social complexity is indicated by the development of elaborate watercraft ca. $700-900$ A.D. We further perceive the advent of this technological innovation as the logical culmination of progressive resource intensification, which was partially an outgrowth of 
human overexploitation of readily accessible marine resources, among which were marine mammal rookeries. When human populations are low, such resources would have been abundant enough to fuel significant population growth, but their potential to sustain such growth is severely limited, and subsequent adaptations would, of necessity, be reliant upon increasingly labor-intensive subsistence strategies. Indeed, the general correlation between coastlines and hunter-gatherer sedentism demonstrated statistically by Pálsson (1988) may reflect the limitations of marine resources and the intensified use of nonmarine foods (e.g., acorns and salmon) and high-cost marine resources such as pelagic fish.

\section{ACKNOWLEDGMENTS}

We thank the following individuals for providing us with data for our study: Carol Cope, Jeff Hall, Mark Hylkema, Deborah Jones, Don Laylander, Roy Salls, Dwight Simons, Mike Walsh, Philip Walker, and Greg White. Data from central and northern California were generated through use of reference collections housed at the Museum of Vertebrate Zoology (University of California, Berkeley), Department of Biology (San Jose State University), and Department of Anthropology (University of California, Davis). We also thank Robert Bettinger for reviewing earlier drafts of this paper, and Rusty Van Rossman for his fine graphic work. Acknowledgment is also due to David Boe for assistance in compiling data tables. All responsibility for errors in fact or judgment, however, remains with the authors.

\section{REFERENCES CITED}

Allen, J. A.

1880 History of North American pinnipeds: A monograph on the walruses, sea-lions, sea-bears, and seals of North America. United States Geological Survey MisAmes, K. M. cellaneous Publications 12

1985 Hierarchies, stress, and logistical strategies among hunter-gatherers in northwestern North America. In Prehistoric hunter-gatherers: The emergence of cultural complexity, edited by T. D. Price and J. A. Brown, pp. 155-180. Academic Press, New York.

Arnold, J. E.

1990 The emergence of complex political economy and linkage to environmental stress in prehistoric coastal California. Paper presented at the 55th Annual Meeting of the Society for American Archaeology, Las Vegas.

Banks, P., and R. Orlins

1981 Investigations of cultural resources within the Richmond harbor redevelopment project 11-A. California Archacological Consulting. Submitted to the City of Richmond, California. Copies available from Northwest Information Center, Department of Anthropology, Sonoma State University,-Rohnert Park, CA 94928.

Basgall, $\mathrm{M}$.

1987 Resource intensification among hunter-gatherers: Acom economies in prehistoric California. Research in Economic Anthropology 9:21-52.
Baumhoff, M.

1958 California Athabaskan groups. University of California Anthropological Records 16:157-233.

Beddington, J. R., R. J. H. Beverton, and D. M. Lavigne (editors)

1985 Marine mammals and fisheries. Allen and Unwin, Boston, MA.

Bennyhoff, J. A.

1950 California fish spears and harpoons. University of California Anthropological Records 9:295-338.

Best, P. B., and P. D. Shaugnessy

1979 An independent account of Captain Benjamin Morrel's sealing voyage to the south-west coast of Africa in the Antarctic, 1828/29. Fisheries Bulletin of South Africa 12:1-19.

Beverton, R. J. H.

1985 Analysis of marine mammal-fisheries interaction. In Marine mammals and fisheries, edited by J. R. Beddington, R. J. H. Beverton, and D. M. Lavigne, pp. 3-33. Allen and Unwin, Boston, MA

Bickel, P. M.

1978 Changing sea levels along the California coast: Anthropological implications. The Journal of California Anthropology 5:6-20.

1981 San Francisco Bay archaeology: Sites ALA-328, ALA-13, and ALA-12. Contributions of the University of California Archaeological Research Facility 43.

Billman, B. R., and P. Walker

1990 Prehistoric diet at CA-SMI-1: Analysis of faunal remains from an early period site. Paper presented at the 24th annual meeting of the Society for California Archaeology, Foster City.

Binford, L. R.

1980 Willow smoke and dogs' tails: Hunter-gatherer settlement systems and archaeological site formation processes. American Antiquity 45:4-20.

Bodega Y. Quadra

1865 Primer viaje de . . Bodega Y Quadra . . año de 1775. Annvario de la direccíon de la hidrografia, Año III 1864:279-294

Bonnell, M. L., R. C. Guess, and K. T. Briggs

1983 Marine mammals and seabirds of central and northern California 1980-1983. Report on file, Center for Marine Studies, University of California Santa Cruz. Prepared for Minerals Management Service, Pacific OCS Region, U.S. Department of the Interior, Contract 14-12-0001-29090.

Bonnot, $\mathrm{P}$.

1928 The sea lions of California. California Fish and Game 14:1-16.

1951 The sea lions, seals and sea otter of the California coast. California Fish and Game 37:371-389.

Boulva, J., and I. A. McLaren

1979 Biology of the harbor seal, Phoca vitulina in eastern Canada. Bulletin of the Fisheries Research Board of Canada 200:1-24.

Breschini, G., and T. Haversat

1980 Preliminary archaeological report and archaeological management recommen dations for CA-MNT-170, on Pescadero Point, Monterey County, California. Report on file Archaeological Consulting, Salinas, California.

1989 Archaeological investigations at CA-MNT-108, at Fisherman's Wharf, Monterey, Monterey County, California. Coyote Press Archives of California Prehistory 29. 
Busby, C.

1975 A mammalian faunal analysis of CA-ALA-307. In West Berkeley (CA-ALA-307): A culturally stratified shellmound on the east shore of San Francisco Bay, edited by W. J. Wallace and D. W. Lathrap, pp. 99-106; Contributions of the Archaeological Research Facility 29.

Carpenter, A

1887 Monkeys Opening Oysters. Nature 36:53

Carrico, R. L., and C. Taylor

1983 Excavation of a portion of Ystagua: A coastal Village Ipai settlement. Report on file Southern Information Center, California Archaeological Site Inventory Social Sciences Institute, California State University, San Diego.

Cartier, $\mathbf{R}$.

1984 The Saunders site (CA-MNT-391): Excavation and preliminary analysis. Paper presented at the Society for California Archaeology northern data sharing meeting, Aptos, California.

1988 The completion of fieldwork at the Scotts Valley site (CA-SCR-177). Pape presented at the 22nd Annual Meeting of the Society for California Archaeology, Reddit.tg.

Christenson, L.

1991 A settlement and subsistence system for the late prehistoric people of San Diego County. Paper presented at the 56th annual meeting of the Society for American Archaeology.

Clark, J. G. D.

1946 Seal hunting in the Stone Age of north-western Europe. A study in economic prehistory. Proceedings of the Prehistoric Society 2:12-48.

Clark, M. R.

986 Archaeological investigations of the Mussel Rock site, CA-SMA-72, San Mateo County, California. Report on file, Northwestern Information Center, California Archaeological Site Survey, Sonoma State University, Rohnert Park, CA.

Colten, $\mathbf{R}$.

1987 Intrasite Variability in Early and Middle Period Subsistence Remains from CA SBA-143, Goleta, Santa Barbara County, California. Archives of California Prehistory 13.

Cope, C.

1985 The mammalian fauna of the Emeryville shellmound CA-ALA-309. M.A. thesis, California State University, Sonoma, Rohnert Park, CA.

Coulson, J. C., and G. Hickling

1964 The breeding biology of the grey seal, Halichoerus grypus. (Fab), on the Farne Islands, Northumberland. Journal of Animal Ecology 33:485-512.

Delaney, M. J.

1982 Mammal ecology. Blackie and Son Limited, New York.

Dietz, S., W. R. Hildebrandt, and T. Jones

1988 Archaeological investigations at Elkhorn Slough: CA-MNT-229 a middle period site on the central California coast. Papers in Northern California Anthropology 3.

Dietz, S., and T. L. Jackson

1981 Report of archaeological excavations at nineteen archaeological sites for the Stage 1 Pacific Grove-Monterey consolidation project of the regional sewerage system. Archaeological Consulting and Research Services. Submitted to Engineering-Science, Berkeley. Copies available from Archaeological Consulting and Research Services, Santa Cruz.
Drucker, $\mathrm{P}$

1937 The Tolowa and their southwest Oregon kin. University of California Publica tions in American Archaeology and Ethnology 36:221-300.

Eberhardt, L. L.

1977 Optimal policies for conservation of large mammals with special reference to marine ecosystems. Environmental Conservation 4:205-212.

Elsasser, A. B.

1978 Development of regional prehistoric cultures. In Handbook of North American Indians volume 8 California, edited by R. F. Heizer, pp. 37-57. Smithsonian Institution, Washington, DC

Engelbrecht, W. E., and C. K. Seyfert

1991 Possible paleoindian watercraft and its implications. Paper presented at the annual meeting of the Eastern States Archaeological Federation, Williamsburg, VA

Erlandson, J.

1988 Of millingstones and molluscs: Cultural ecology of early Holocene huntergatherers on the California coast. Ph.D. dissertation, University of California Santa Barbara.

Estes, J. A.

1979 Exploitation of marine mammals: R-selection of k-strategists? Journal of the Fisheries Research Board of Canada 36:1009-1017.

Fiscus, C. H.

1978 Northern fur seal. In Marine mammals, edited by D. Haley, pp. 153-159. Pacific Search Press, Seattle, WA.

Fredrickson, D. A.

1984 The north coastal region. In California Archaeology, edited by M. J. Moratto, pp. 471-528. Academic Press, San Francisco.

Gallegos, D.

1987 A review and synthesis of environmental and cultural material for the Batiquitos Lagoon region. In San Dieguito-La Jolla: Chronology and controversy, edited by D. Gallegos, pp. 23-34. San Diego County Archaeological Society Research Paper No. 1.

Gallegos, D., and R. Carrico

1984 Windsong shores data recovery program for SDI-48 (W-164) Ballast Point pre historic site. Report on file Southern Information Center, California Archaeological Site Inventory, Social Sciences Institute, California State University, San Diego.

Gallegos, D., and C. Kyle

1988 Five thousand years of maritime subsistence at Ballast Point prehistoric site SDI-48 (W-164) San Diego, California. Report on file Southern Information Center California Archaeological Site Inventory, Social Sciences Institute, California State University, San Diego.

Geraci, J. R., and D. J. St. Aubin

1990 Sea mammals and oil: Confronting the risks. Academic Press, San Diego.

Gifford, D. P., and F. Marshall

1984 Analysis of the archaeological assemblage from CA-SCR-35, Santa Cruz County, California. Coyote Press Archives of California Prehistory 2:1-78.

Glassow, M.

1990 Archaeological investigations on Vandenberg Air Force Base in connection with the development of space transportation system facilities. Report prepared for the Department of Interior, National Park Service, Western Region. Copies 
available from National Technical Information Services, Operation Division 5285 Port Royal Road, Springfield, VA 22161.

1991 The relative dietary importance of marine foods through the prehistory of the Vandenberg region. Paper presented at the 56th annual meeting of the Society for American Archaeology.

Glassow, M., and L. Wilcoxon

1988 Coastal adaptation near Point Conception, California, with particular regard to shellfish exploitation. American Antiquity 51:36-51.

Glassow, M., L. Wilcoxon, and J. Erlandson

1988 Cultural and environmental change during the Early Period of Santa Barbara channel prehistory. In The archaeology of prehistoric coastlines, edited by Geoff Bailey and John Parkington, pp. 64-77. Cambridge Univ. Press, New York.

Goddard, P. E.

1903 Life and culture of the Hupa. University of California Publications in American Archaeology and Ethnology 1:1-88.

Goldberg, C. F

1989 Colunth sample analysis and dietary reconstruction. Anthropology U.C.L.A. 16:24-34.

Goldschimdt, W. R.

1951 Nomlaki ethnography. University of California Publications in American Archaeology and Ethnology 42:303-443.

Gould, R. A.

1968 Seagoing canoes among the Indians of northwestern California. Ethnohistory $15: 11-42$.

1972 A radiocarbon date from the Point Saint George site, northwestern California. Contributions of the University of California Archaeological Research Facility 14:41-44.

Griffin, J. B.

1964 The Northeast woodlands area. In Prehistoric man in the mew world, edited by J. Jennings and E. Norbeck, pp. 223-258. University of Chicago Press, Chicago,

Hector, S. M.

1984 Late prehistoric hunter-gatherer activities in southern San Diego County, CA. Ph.D. dissertation, University of California, Los Angeles.

Heizer, R. F.

1938 A folsom type point from the Sacramento Valley. The Masterkey 12:180-182

Heizer, R. F., and W. C. Massey

1953 Aboriginal navigation off the coasts of upper and Baja California. Bureau of American Ethnology Bulletin 151:285-312.

Hewes, G. W.

1974 Aboriginal use of fishing resources in northwestern North America. Ph.D. dissertation, University of California, Berkeley, CA.

\section{Hildebrandt, W. R.}

1981 Native hunting adaptations of the north coast of California. Unpublished Ph.D. dissertation, Department of Anthropology, University of California, Davis, CA

1984a Late Period hunting adaptations on the north coast of California. Journal of California and Great Basin Anthropology 6:189-206.

1984b Archacological presence of the northern fur seal (Callorhinus ursinus) along the coast of northern California. The Murrelet 65:28-29.
Hildebrandt, W. R., and J. Hall

n.d. Analysis of faunal remains from CA-MNT-391. Ms. in author's possession.

Hildebrandt, W. R, and J. F. Hayes

1983 Archaeological investigations of Pilot Ridge Six Rivers National Forest. Cultural Resources Facility, Sonoma State University. Submitted to USDA Forest Service, Contract No. 53-95HA-2-140. Copies Available from Six Rivers National Forest, Eureka, CA.

Hudson, T. D., and T. C. Blackburn

1982 The material culture of the Chumash interaction sphere. Vol.1: Food procurement and transportation. Ballena Press Anthropological Papers 25.

Hylkema, M.

1991 Prehistoric native American adaptations along the central California coast of San Mateo and Santa Cruz counties. M.A. thesis, California State University, San Jose, CA.

Jennings, J. D.

1986 Prehistory: Introduction. In Handbook of North American Indians Volume 11, Great Basin edited by W. L. d'Avevedo, pp. 113-119. Smithsonian Institution, Washington, DC.

Jobson, R., and W. R. Hildebrandt

1980 The distribution of oceangoing canoes on the north coast of California. Journal of California and Great Basin Anthropology 2:165-174.

Jones, D. A., and W. R. Hildebrandt

1990 Archaeological investigations at Sand Hill Bluff: Portions of prehistoric site CA-SCR-7, Santa Cruz County, California. Report on file, Northwest Information Center, California Archaeological Site Inventory, Department of Anthropology, Sonoma State University, Rohnert Park, CA.

Jones, T. L.

1988 A shell projectile point from the Big Sur coast, California. Journal of California and Great Basin Anthropology 10:100-103.

1989a Marine resource value and the priority of coastal settlement among huntergatherers: A California perspective. M.A. thesis, Department of Anthropology, University of California, Davis.

1989b Surface archaeology at Landels-Hill Big Creek Reserve and the Gamboa Point properties, Monterey County, California. University of California, Santa Cruz Environmental Field Program Publication 18.

1991 Marine-resource value and the priority of coastal settlement: A California perspective. American Antiquity 56:419-443.

n.d. Ph.D. dissertation. University of California, Davis, in preparation.

Keene, A.

1983 Biology, behavior, and borrowing: A critical examination of optimal foraging models in archaeology. In Archaeological hammers and theories, edited by A. Keene, and J. Moore, pp.137-156. Academic Press, New York.

Kenyon, K. W.

1978 Sea otter. In Marine mammals of the eastern north pacific and arctic waters, edited by D. Haley, pp. 226-235. Pacific Search Press, Seattle, WA.

1982 Sea otter. In Wild mammals of North America, edited by J. A. Chapman, and G. A. Feldhamer, pp. 704-710. John Hopkins University Press, Baltimore, MD.

King, C.

1982 The evolution of chumash society: A comparative study of artifacts used in social system maintenance in the Santa Barbara Channel region. Ph.D. dissertation, University of California, Davis. 
1990 Evolution of Chumash society a comparative study of artifacts used for social system maintenance in the Santa Barbara Channel region before A.D. 1804

King, J. E, Garland Publishing, New York

1983 Seals of the world. 2nd ed. Cornell University Press, Ithaca, New York.

King, L. B.

1982 Medea Creek cemetery: Late inland Chumash patterns of social organization, exchange and warfare. Ph.D. dissertation, University of California, Los Angeles, CA.

Koerper, H. C.

1981 Prehistoric subsistence and settlement in the Newport Bay area and environs, Orange County, California. Unpublished Ph.D. dissertation, University of California, Riverside, CA.

1986 The Agua Hedionda Project: Archaeological Investigations at CA-SDI-5353 and CA-SDI-9649. Report on file Southern Information Center, California Archaeological Site Inventory, Social Sciences Institute, California State University, San Diego, CA.

\section{Kroeber, A. L.}

1922 Elements of culture in native California. University of California Publications in American Archaeology and Ethnology 13:259-328.

1925 Handbook of the Indians of California. Bureau of American Ethnology Bulletin 78. Smithsonian Institution, Washington, DC.

Kroeber, A. L., and S. A. Barrett

1960 Fishing among the Indians of northwestern California. University of California Anthropological Records 21:1-210.

Landberg, L. C. W.

1965 The Chumash Indians of southern California. Southwest Museum Papers 19:1158.

Le Bouef, B. J.

1981 Elephant Seals. In The Natural History of Año Nuevo, pp. 326-374. Boxwood Press, Pacific Grove, CA

Levulett, V. A.

1985 The prehistory of southwestern Humboldt County: A study of coastal archaeological sites in the King Range National Conservation Area. Ph.D. dissertation, University of California, Davis, CA.

Levulett, V. A., and W. R. Hildebrandt

1987 The King Range Archaeological Project: Results of the 1984 Field Season. Report on file Bureau of Land Management, Ukiah.

Love, J. A.

1990 Sea otters. Whittet Books, London.

Lyon, G. M.

1937 Pinnipeds and a sea otter from the Point Mugu Shellmound of California. University of California at Los Angeles Publications in Biological Sciences 1:133255.

Lyman, R. L.

1989 Seal and sea lion hunting: A zooarchaeological study from the southern northwest coast of North America. Journal of Anthropological Archaeology 8:68-99.

1991 Prehistory of the Oregon Coast. Academic Press, New York.

Lyman, R. L., and R. E. Ross

1988 Oregon coast archaeology: A critical history and a model. Northwest Anthropological Research Notes 22:67-119.
Lyman, R. L., L. A. Clark, and R. E. Ross

1988 Harpoon stone tips and sea mammal hunting on the Oregon and northern California coasts. Journal of California and Great Basin Anthropology 10:73-87.

Macko, M., and R. D. Mason

1990 The Irvine coast archaeological project: Managing the incorporation of scientific applications in southern California CRM. Paper presented at the 55th annual meeting of the Society for American Archaeology.

Marean, C. W.

1986 On the seal remains from Klasies River Mouth: An evaluation of Binford's Interpretations. Current Anthropology 27:365-367.

Martin, J. F.

1983 Optimal foraging theory: A review of some models and their applications. American Anthropologist 85:612-629.

Martz, P. C.

1984 Social dimensions of Chumash mortuary populations in the Santa Monica Mountains region. Ph.D. dissertation, University of California, Riverside, CA.

Mate, B. R.

1975 Annual migrations of the sea lions Eumetopias jubata and Zalophus califor nianus along the Oregon coast. Rapports et Proces-Verbaux 169:455-461.

Maxwell, G.

1967 Seals of the world. Houghton Mifflin, Boston.

McCrossin, M. L.

1982 Paleoecological inferences from a faunal analysis of CA-SFR-07. Journal of California and Great Basin Anthropology 4:138-141.

McLaren, I. A., and T. G. Smith

1985 Population ecology of seals: Retrospective and prospective views. Marine Mammal Science 1:54-83.

Mertz, D. B.

1971 The mathematical demography of the California condor population. American Naturalist 105:437-453.

Newby, T. C.

1973 Observations on the behavior of the harbor seal in the state of Washington. Journal of Washington 54:540-543.

1978 Pacific harbor seal. In Marine mammals, edited by D. Haley, pp. 185-191. Pacific Search Press, Seattle, WA.

Origer, T., and D. A. Fredrickson

1980 The Laguna archaeological research project, Sonoma County. Anthropological Studies Center, California State University Sonoma. Submitted to Public Works Department, City of Santa Rosa. Copies available from Anthropological Studies Center.

Orr, R. T., and R. C. Helm

1989 Marine mammals of California. University of California Press, Berkeley, CA.

Orr, R. T., and T. C. Poulter

1967 Some observations on reproduction, growth, and social behavior in the Steller sea lion. Proceedings of the California Academy of Sciences 35:193-226.

Osborn, A.

1977 Strandloopers, mermaids, and other fairy tales: Ecological determinants of marine resource utilization-the Peruvian case. In For theory building in archaeology, edited by L. R. Binford, pp. 157-206. Academic Press, San Francisco.

Owen, R. C., F. Curtis, and D. S. Miller

1964 The Glen Annie Canyon site, $\mathrm{SBa142}$ an early horizon coastal site of Santa 
Barbara County. University of California, Los Angeles Archaeological Survey Annual Report, 1963-1964:429-517.

Oxendine, J.

1983 The Luiseno village during the late prehistoric era. Ph.D. dissertation, University of California, Riverside, CA.

Pálsson, G.

1988 Hunters and gatherers of the sea. In Hunters and gatherers 1: History, evolution and social change, edited by T. Ingold, D. Riches, and J. Woodburn, pp. 189 204. Berg Publishers Limited, New York.

Pastron, A., and M. Walsh

1988a Archaeological excavations at CA-SFR-112, the Stevenson Street shellmound, San Francisco, California. Coyote Press Archives of California Prehistory 21.

1988b Archaeological excavations at CA-SFR-113, the Market Street shell midden, San Francisco, California. Coyote Press Archives of California Prehistory 25.

Peterson, R. R.

1984 Early/middle period subsistence changes at SBA-1, Rincon Point, California. Journgl of California and Great Basin Anthropology 6:207-216.

Powers, S.

1877 Tribes of California. Contributions to North American ethnology 3, U.S. Geographical and Geological Survey of the Rocky Mountain Region, WA

Price, T. D., and J. A. Brown

1985 Prehistoric hunter-gatherers the emergence of cultural complexity. Academic Press, New York.

Quintero, L.

1987 Room and board at deer springs: Faunal analysis as an aid to settlement studies. M.A. thesis, California State University, San Diego.

Radford, K. W., R. T. Orr, and C. L. Hubbs

1965 Reestablishment of the northern elephant seal, Mirounga angustirostris, off central California. Proceedings of the California Academy of Sciences 31:601612.

Reiter, J., K. J. Panken, and B. J. Le Bouef

1981 Female competition and reproductive success in northern elephant seals. Animal Behaviour 29:670-687.

\section{Riedman, $\mathrm{M}$.}

1990 The Pinnipeds: Seals, Sea Lions and Walruses. University of California Press, Berkeley, CA.

Rogers, D. B

1929 Prehistoric man of the Santa Barbara coast. Santa Barbara Museum of Natural History.

Ronald, K., J. Selly, and P. Healy

1982 Seals. In Wild animals of North America, edited by J. A. Chapman and G. A. Rowley, J. Feldhammer, pp. 769-827. John Hopkins University Press, Baltimore.

1929 Life history of the sea lions on the California coast. Journal of Mammology 10:1-36.

Rudkin, C. N. (editor)

1956 Observations on California 1772-1790, by Fr. Luis Sales, O.P. Glen Dawson, Los Angeles.
Scammon, C. M.

1874 The marine mammals of the northwestern coast of North America. John Carmany and Sons, San Francisco, CA.

Schalk, R. F.

1977 The structure of an anadromous fish resource. In For theory building in archaeology, edited by L. Binford, pp. 207-249. Academic Press, New York.

Scheffer, V. B.

1958 Seals, sea lions, and walruses. Stanford University Press, Stanford.

Schwaderer, R., J. Ferneau, and E. B. Parkman

1990 Coyote's hole: Preliminary investigations at CA-SON-348, the Duncan's Landing cave site. Paper presented at the 24th annual Meeting of the Society for California Archaeology.

Shipek, F.

1977 A strategy for change: The Luiseno of southern California. Ph.D. dissertation, University of Hawaii.

1982 Kumeyaay socio-political structure. Journal of California and Great Basin Anthropology 4:296-303.

Simons, D. D.

1981 Bird and mammal remains from eight archaeological sites (CA-Mnt-107, -110, $-111,-112,-113,-114,-115,-116)$, located in Pacific Grove, Monterey County, California. In Report of archaeological excavations at nineteen archaeological sites for the Stage 1 Pacific Grove-Monterey consolidation project of the regional sewerage system, edited by S. Dietz, and T. L. Jackson, pp. D1-D43. Submitted to Engineering-Science, Berkeley. Copies available from Archaeological Consulting and Research Services, Santa Cruz.

1990 Vertebrate remains from the Albion sites. In Western Pomo prehistory: Excavations at Albion Head, Nightbirds Retreat, and Three Chop Village, Mendocino County, California; University of California, Los Angeles, CA. Institute of Archaeology Monographs 32.

1991 Prehistoric exploitation of mammals around San Francisco Bay. Paper presented at the Annual Meeting of the Society for California Archaeology, New Orleans.

Smith, E. A.

1983 Anthropological applications of optimal foraging theory. Current Anthropology 24:625-651.

Snyder, S. L.

1978 An osteo-archaeological investigation of pinniped remains at Seal Rock, Oregon. M.A. thesis, Oregon State University, Corvallis, OR.

Starks, E.C.

1922 Records of captures of fur seals on land in California. California Fish and Game 8:155-160.

Stirling, I

1983 The evolution of mating systems in pinnipeds. In Recent advances in the study of mammalian behavior, edited by J. F. Eisenberg and D. G. Kleiman, pp. 489-527. Special Publication of the American Society of Mammalogy.

Testart, A.

1982 The significance of food storage among hunter-gatherers: Residence patterns, population densities and social inequalities. Current Anthropology 23:523-537. 
True, D. L.

1966 Archaeological differentiation of Shoshonean and Yuman speaking groups in southern California. Ph.D. dissertation, University of California, Los Angeles, CA.

Wagner, H. R.

1929 Spanish voyages to the northwest coast of America in the sixteenth century. California Historical Society Special Publications 4.

Walker, P. L., and S. Craig

1979 Archaeological evidence concerning the prehistoric occurrence of sea mammals at Point Bennett, San Miguel Island. California Fish and Game 65:50-54.

Walker, P. L., and P. E. Snethkamp

1984 Final report archaeological investigations on San Miguel Island-1982 prehistoric adaptations to the marine environment. Report submitted to National Park Service, Western Region, 450 Golden Gate Avenue, Box 36063, San Francisco. CA.

Wallace, $W$

1955 A suggested chronology for southern California coastal archaeology. Southwest ern Journal of Anthropology 11:214-230.

Wallace, W., and D. W. Lathrap

1975 West Berkeley (CA-ALA-307): A culturally stratified shellmound on the eas shore of San Francisco Bay. Contributions of the University of California Archaeological Research Facility, 29.

Warren, C. N.

1968 Cultural tradition and ecological adaptation of the southern California coast. In Archaic Prehistory in the Western United States, edited by C. Irwin-Williams, pp. 1-14. Eastern New Mexico University Contributions in Anthropology 1:1-14.

Warren, C. N., and M. G. Pavesic

1963 Shell midden analysis of site SDI-603 and ecological implications for cultural development of Batiquitos Lagoon, San Diego County. University of California Los Angeles Archaeological Survey Annual Report 1962-1963: 407-438.

Warren, C. N., D. L. True, and A. A. Eudey

1961 Early gathering complexes of western San Diego County: Results and interpretations of an archaeological survey. University of California, Los Angeles, Archaeological Survey Annual Report 1960-1961:1-106.

Waterman, T. T.

1920 Yurok geography. University of California Publications in American Archaeology and Ethnology 16:177-314.

Watts, D. C.

1984 Bones along the bayshore: A study of mammalian exploitation and cultural taphonomy of faunal assemblages from two bayshore shellmounds, CA-ALA328 and $C A-A L A-329$. M.A. thesis, California State University, Hayward, CA.

West, G. J.

1989 Late Pleistocene/Holocene vegetation and climate. In Prehistory of the Sacramento River Canyon, Shasta County, California, edited by M. C. Basgall and W. R. Hildebrandt, pp. 36-55. Center for Archaeological Research at Davis Publication 9.

1990 Holocene fossil pollen records of douglas fir in northwestern California: Reconstruction of past climate. In California Department of Water Resources, Interagency Ecological Studies Program Technical Report 23.
White, G.

1988 Dune site excavations at Mackerricker State Park. Paper presented at the Northern Data Sharing Meeting of the Society for California Archaeology, Sacramento.

n.d. Ph.D. dissertation. University of California, Davis, in preparation.

Yesner, D. R.

1980 Maritime hunter-gatherers: Ecology and prehistory. Current Anthropology 21:727-750. 